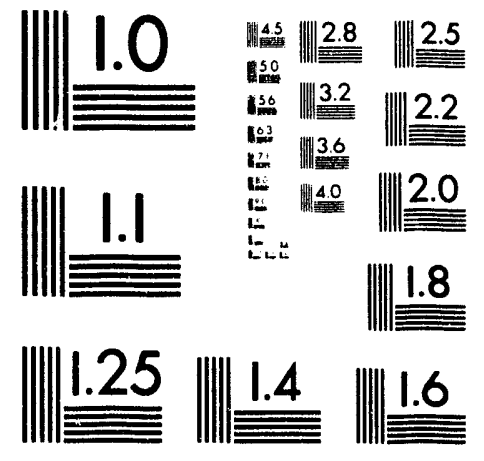



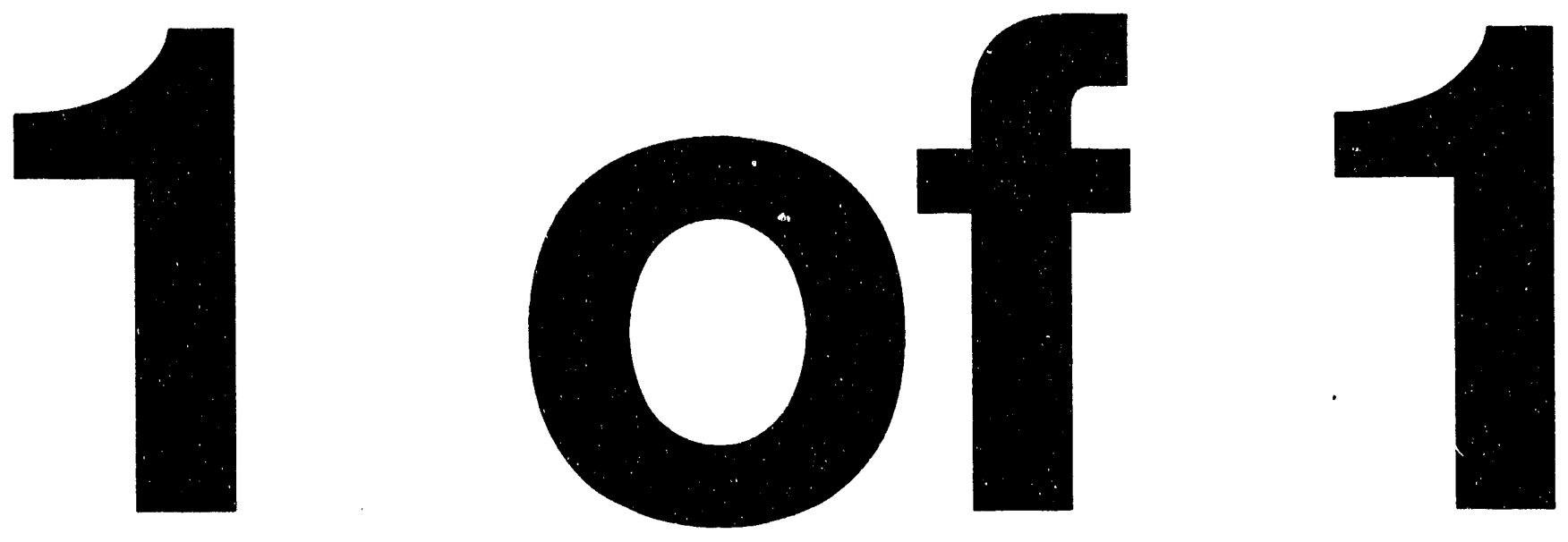
WHC-EP-0662

\section{Summary Report on 49 L Ferrocyanide Aerosol Tests TO208-1 and TO209-1}

Prepared for the U.S. Department of Energy Office of Environmental Restoration and Waste Management

\section{(2.) Westinghouse \\ Hanford Company Richland, Washington}

Hanford Operations and Engineering Contractor for the

U.S. Department of Energy under Contract DE-AC06-87RL10930 


\section{LEGAL DISCLAIMER}

This report was prepared as an accouni of woik sponsored by an agency of the United States Government. Nelther the

United States Government nor any agency inereof, nor any of the ir employeas. nor any of their contractors. subcontractors or their employees, makes any warranly, express or implied, or assumes any legal liability or responsibility for the accuracy, completeness, or any third party's use or the results of such use of any intormation, apoaratus, product, or process disclosed. or represents that its use would not infringe privalely owned righis. Peference herein 10 any specific commercial product, orocess, or service by irade name, irademark, manufacturer. or otherwise, does not necessarily constitute or imply its endorsement. recommendation, or favoring by the Unired States Govarnment or any agency thereof or its contractors or subcontractors. The views and opinions of authors expressed herein do not necessarly state or reflect those of the United States Government or any agency thereot.

This report tas been reproduced from the best avallabie copy. Available in paper copy and microficho.

Available to the U.S. Department of Energy and its contractors from

Office of Scientific and Technical Information P. 0 . Box 62

Oak Ridge. TN 37831

(615) 576.8401

Available to the public from the U.S. Department of Commerce National Technical Information Service

5285 Port Royal Road

Springfield, VA 22161

(703) $487-4650$

Printed in the Unitod States of Amorica

DISCLM.1.CHP $11 \cdot 31)$ 


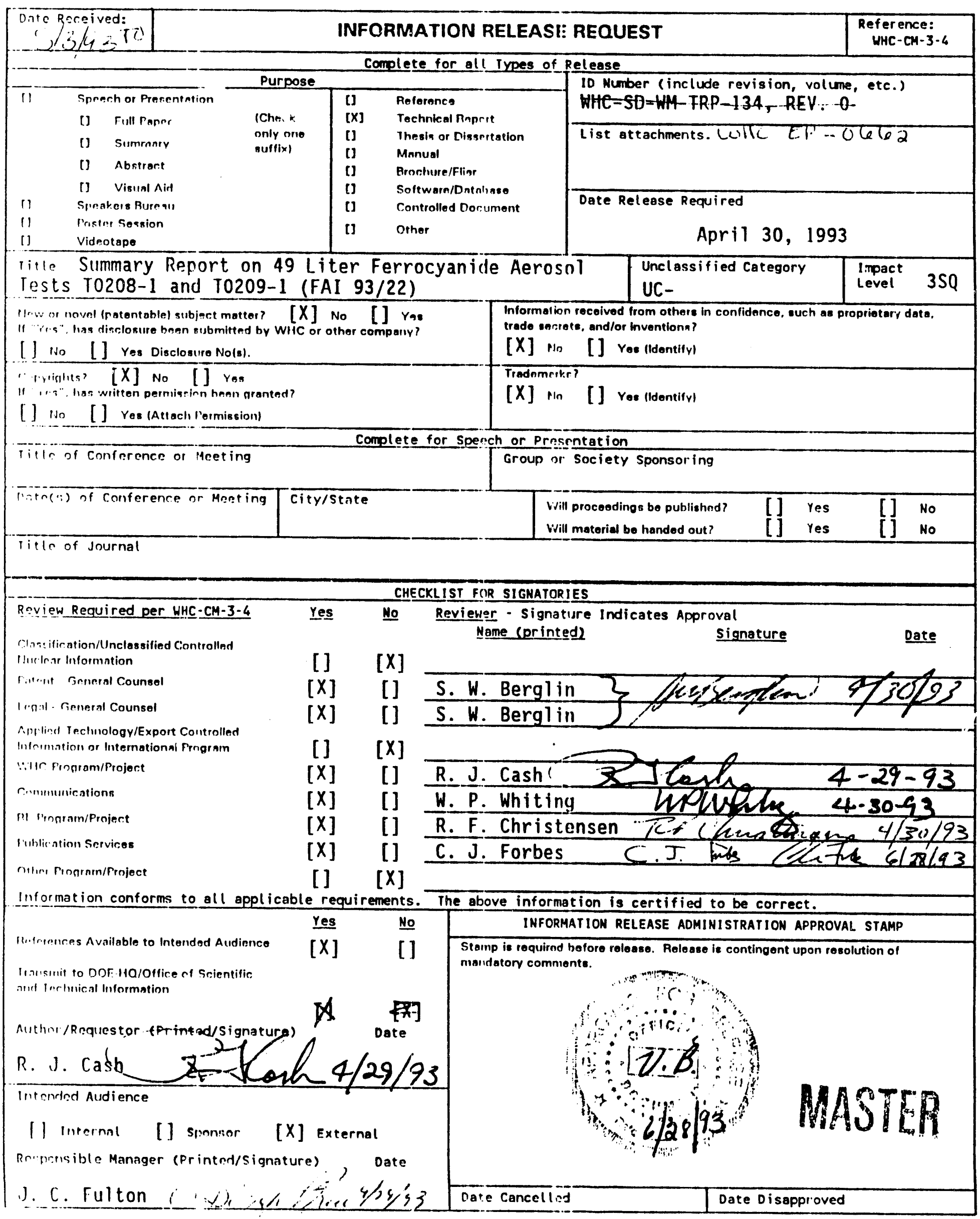

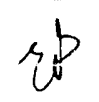


WHC-EP-0662

UC-600

\section{Summary Report on $49 \mathrm{~L}$ Ferrocyanide Aerosol Tests TO208-1 and TO209-1}

H. K. Fauske

Fauske and Associates, Inc.

Burr Ridge, Illinois 60521

Date Published

June 1993

Prepared for the U.S. Department of Energy Office of Environmental Restoration and Waste Management

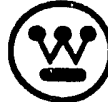

Westinghouse

P.O. Box 1970

Hanford Company Richland, Washington 99352

Hanford Operations and Engineering Contractor for the

U.S. Department of Energy under Contract DE-AC06-87RL10930 


\section{ITST OP TARIRS}

\section{Table no.}

Material Assay of In-Farm-1 Bottom Flow Sheet Sample . . 3-1

$3-2$

Final As-Tested Sample Parameter

$5-1$

Reaction Speed Data for Test T0127-1

$6-1$

\section{ITST OF FTGORRS}

\section{Eleure bo.}

2-1 Overall test equipment configuration with 49L contalnment vesse 1 and $25 \mathrm{~mm}$ dia. sample holder with aerosol filter and orifice unit ... . . . . . . 2-2

2.2 40 liter containment vessel ............. 2-3

2-3 25 diameter sample holder used in burn velocity tests.... . . . . . . . . . . . . . . . . . . . . 2-4

5-1 Thermocouple response data showing reaction propagation speed for Infarm-1 bottom, dry sample, $100 \mu, 60^{\circ} \mathrm{C}, 10$ acm. abs., average speed is $.26 \mathrm{~cm} / \mathrm{sec}$. . . . . . . . . 5.2

5-2 Containment response to reaction propagation test T0127-1................... . 5-3 
WHC-EP-0662

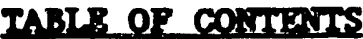

1.0 INTRODUCTION AND SUMRARY .................... . 1 . . .

2.0 TEST EQUIPMENT ........................ 2.1

2.1 Reaction Ignition Source ................. 2-1

3.0 TEST MATERIALS ....................... 3-1

4.0 TEST PROCEDURES ...................... . 4.1

5.0 TEST RESULTS . . . . . . . . . . . . . . . . . . . . . . 5.1

5.1 Propagation Rate Data . . . . . . . . . . . . . . . . . 5-1

5.2 Overall Containment Environment Response . . . . . . . . . 5-1

5.3 Post-Test Observations . . . . . . . . . . . . . . . . . . 5.4

6.0 COMPARISON WITH OTHER RELATED RESULTS . . . . . . . . . . . . 6-1

7.0 REFERENCES . . . . . . . . . . . . . . . . . . . 7.1

APPENDIX A: Letter from R. J. Cash to H. K. Fauske, (Ref. [1]) . . . A-I APPENDIX B: Test Procedures .................... B-I APPENDIX C: Miscellaneous Test Data Records.............. . C-I 


\subsection{INIRODOGIOT AND SURYARY}

This report presents the results of the first test conducted in a series of tests directed by Westinghouse Hanford Company (WHC) in Ref. [1]. For the record, Ref.[1] is included as Appendix $A$. The test discussed in this document, designated as T0127-1, is a ferrocyanide reaction propagation rate determination test conducted under an inert argon atmosphere of $10 \mathrm{~atm}$. abs. ( $130 \mathrm{psig}$ ). The test was conducted in a new $49 \mathrm{~L}$ containment volume described in Section 2.0. The test sample was dry In-Farm 1 bottom flow sheet material described in Section 3.0. The test protocol was similar to that described in Refs. [2 and 3]. However, as requested in Ref. [1] supplemental gas sample taking procedures were prepared and followed as described in Section 4.0 and Appendix B.

Test results showed an inverse reaction propagation velocity of $\approx 4$ $\mathrm{sec} / \mathrm{cm}$. This is about 50 faster than a prior similar test conducted under 1 atm. abs. pressure. For further comparison, this burn velocity of the ferrocyanide test is also about an order-of-magnitude slower than a slow burn gun powder at $1 \mathrm{~atm}$. Pre- and post-test gas samples were taken and have been forwarded to whC for further analyses. Detalls of these results are presented in Section 5.0 and comparisons with other similar reaction propagation rate tests are discussed in Section 6.0. 


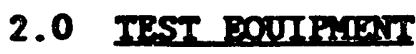

The overall test equipment configuration is shown in Fig. 2-1. This configuration is similar to the configuration used in earlier tests, Ref. [2], but features a $49 \mathrm{I}$ containment vessel. The $49 \mathrm{I}$ containment vessel and environment thermocouple locations are shown in Fig. 2-2. Fig. 2-3 shows detalls of the $25 \mathrm{~mm}$ diameter sample holder. The sample holder is a 0.002 inch thick, type 316 stainless steel sheet rolled onto a $25 \mathrm{~mm}$ diameter mold, spot welded to hold a round tube configuration and trimmed to 4 inches in overall length. This tube (considered to be disposable) is slipped over the base stand as shown in Fig. 2-3. After the sample tube is filled with the test sample material, a spiral heater coil is positioned on the outside of the tube wall and type $K$ thermocouples of 0.020 inch diameter are located at the indicated axial elevations.

\subsection{Reaction Ientition Source}

The use of a barium peroxide and aluminum mixture has proven to be an effective starter for the ferrocyanide reaction. This starter mixture can be ignited with a hot wire. The stoichiometric reaction is written as

$$
\underset{(169.34)}{3 \mathrm{BaO}_{2}}+\underset{(26.98)}{2 \mathrm{Al}} \rightarrow \underset{(153.34)}{3 \mathrm{BaO}}+\underset{(101.96)}{\mathrm{Al}_{2} \mathrm{O}_{3}}
$$

Numbers in ( ) under the above reaction represent the formula weights of the reactants and products. Thermochemical evaluation of this stoichiometric relation indicates a heat of reaction estimated to be $-338 \mathrm{kcal} / \mathrm{g}-\mathrm{mole} \mathrm{BaO}_{2}$ or $\approx 9.5 \mathrm{~mJ} / \mathrm{kg} \mathrm{BaO}$. The estimated reaction temperature increase is of the order of $2000^{\circ} \mathrm{C}$. This reaction is used to initiate the thermite reactions $\left(\mathrm{Fe}_{2} \mathrm{O}_{3}+2 \mathrm{Al} \rightarrow 2 \mathrm{Fe}\right)$. The barium peroxide-aluminum reaction as written does not appear to be gassy. Barium oxide, mp $2000^{\circ} \mathrm{C}$, bp $3100^{\circ} \mathrm{C}$, appears to be quite stable $\left(\mathrm{Al}_{2} \mathrm{O}_{3}\right.$ has a boiling point of $\left.2900^{\circ} \mathrm{C}\right)$. However, $\mathrm{BaO}_{2}$ is reported to decompose to $\mathrm{Ba}$ and $\mathrm{O}_{2}$ at $800^{\circ} \mathrm{C}$. This could be a source of gas, albeit small, for this ignition method. The barium peroxide/Al starting 


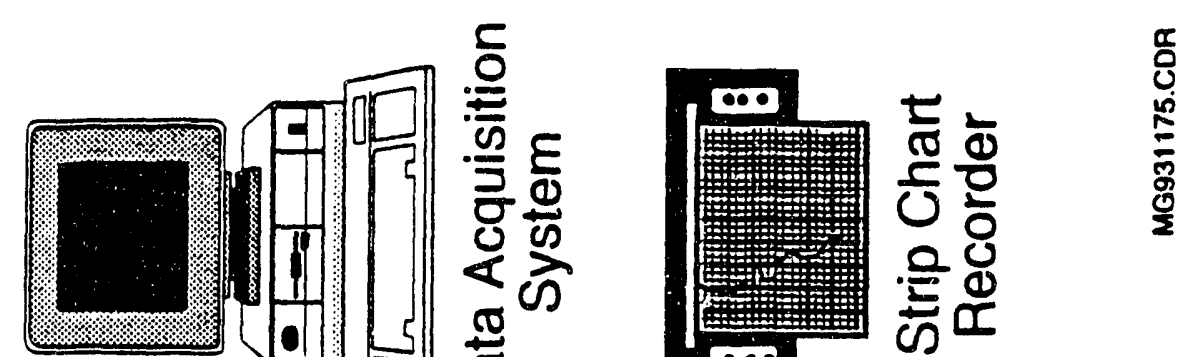

ต
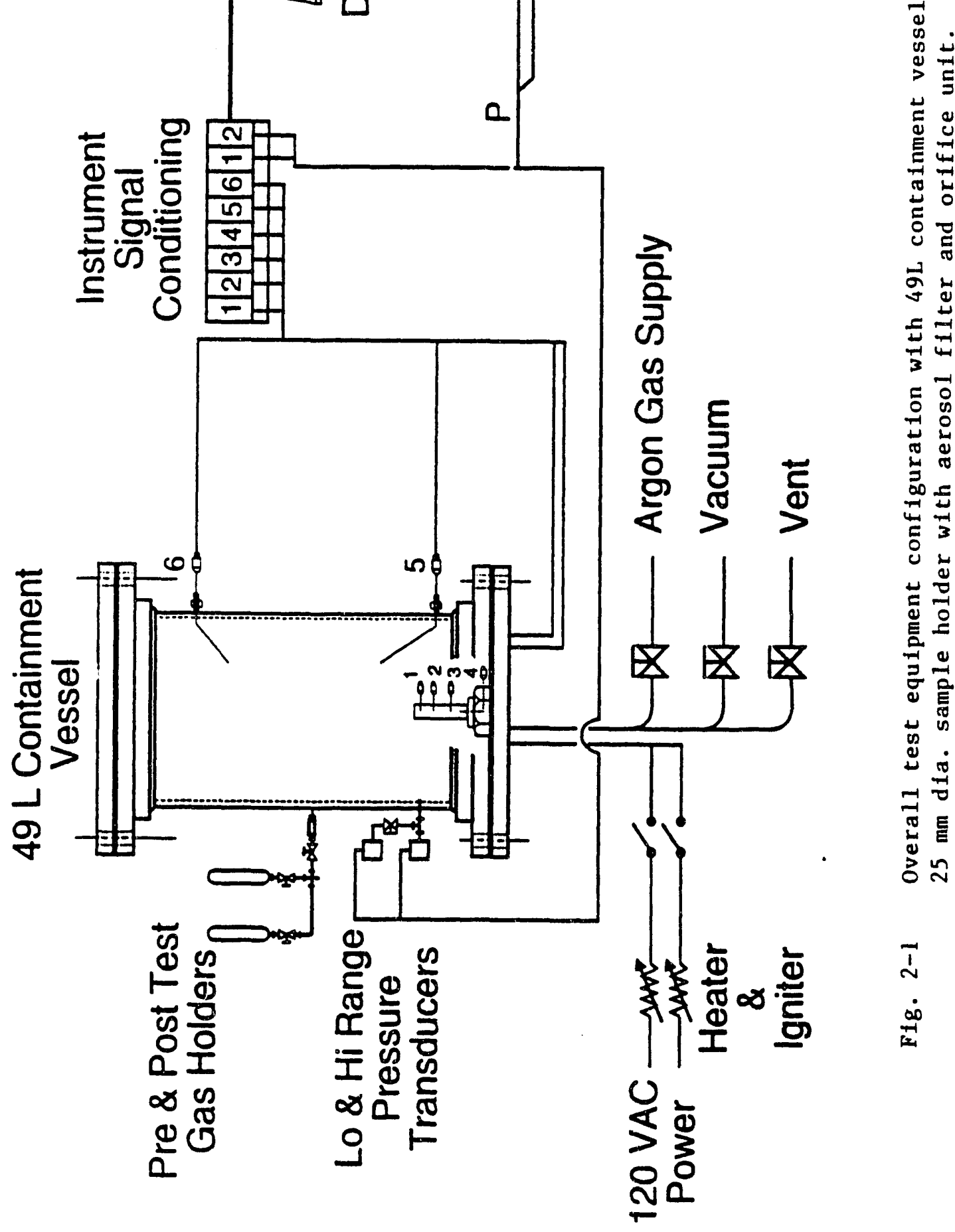
WHC-EP-0662

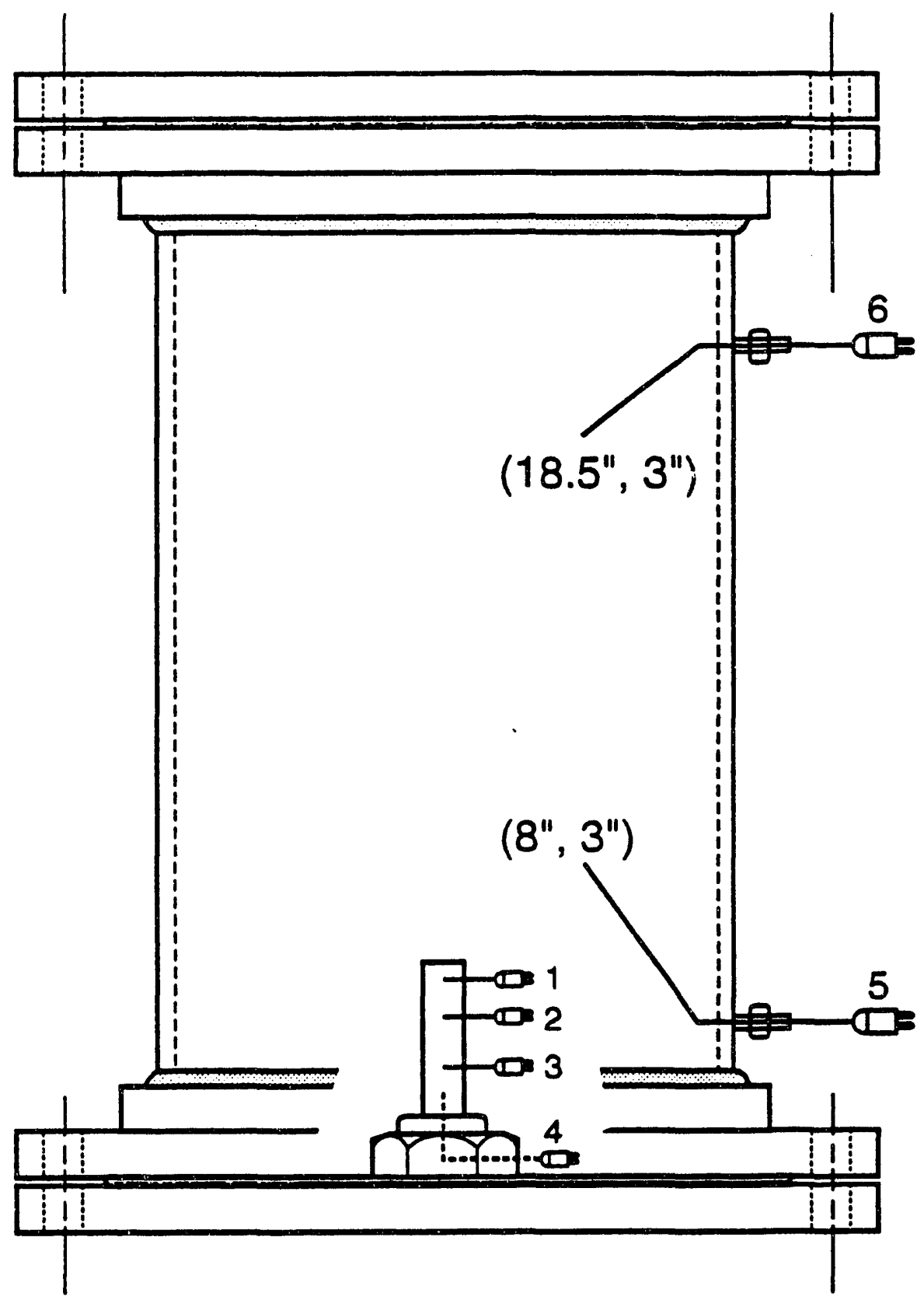

MG931169.CDR

F1g. 2-2 40 liter containment vessel.

12" ID $\times 0.375^{\prime \prime}$ wall $\times 26$ " Iong with $1501 \mathrm{~b}$. flanged ends as shown with 1 " dia $\times 4$ " long sample holder shown to scale. $(y, r)$ indicates TC location relative to bottom $(y)$ and away from wall $(r)$. 


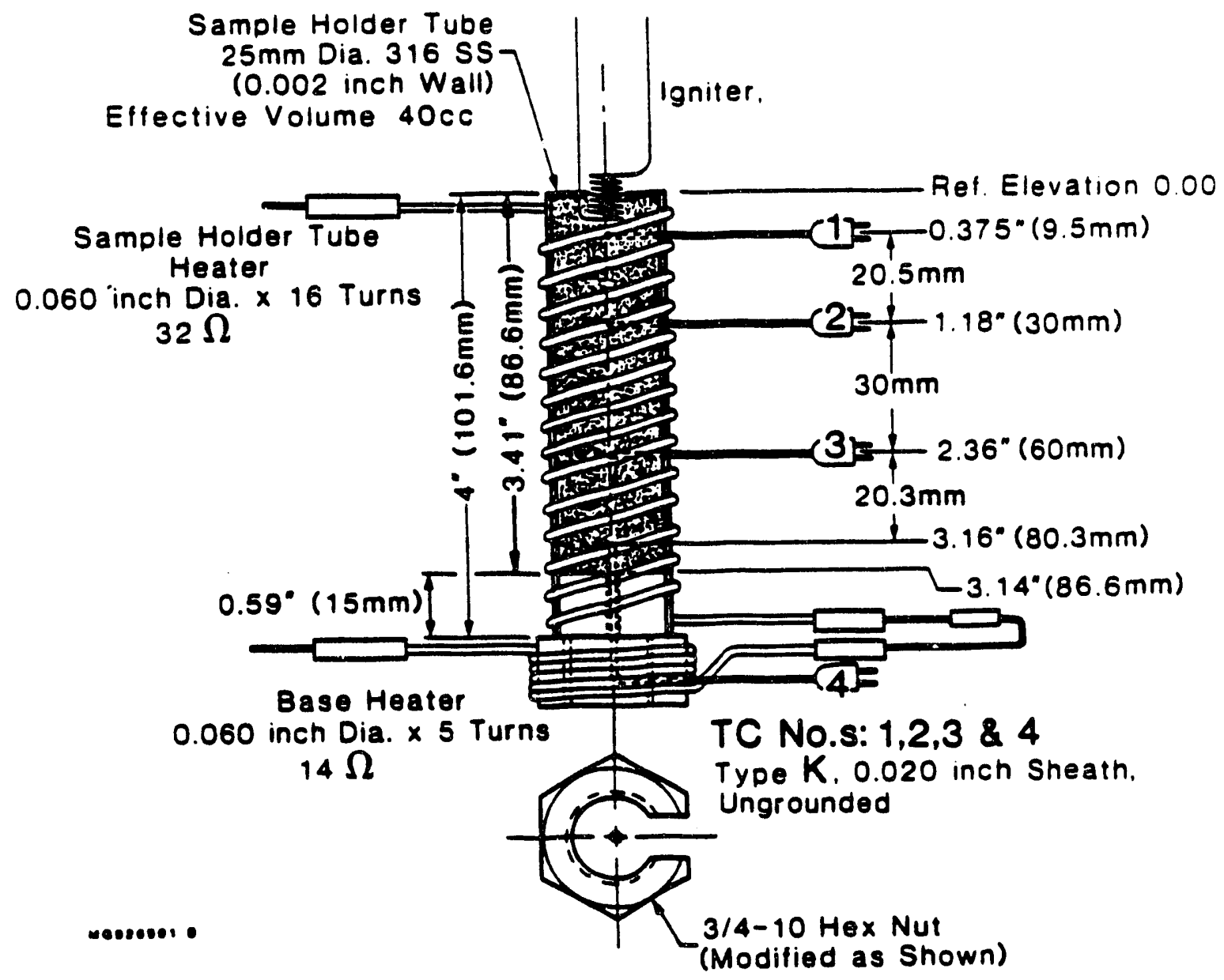

P18. 2-3 25 dianeter sample holder used in burn velocity tests. 
WHC-EP.-0662

mixture will be separated from the ferrocyanide column by a thin aluminum foil. The ignition nethod has been used, as described, in previous propagation rate studies, Ref. [2]. 


\subsection{TEST MATMETATS}

The test sample used in this test, T0127-1, was In-Farm 1 bottom flow sheet material received from WHC. The material was vacuum dried and then sieved through a 140 mesh U.S. standard screen having a $106 \mu$ mean particle size. The test sample assay is estimated to be as stated in Table 3.1 based on information provided by whC.

Table 3-1

Material Aseas of

In-Farm-1 Botton For sheet Saple

\begin{tabular}{|c|c|}
\hline Material & wt. \& \\
\hline $\begin{array}{l}-\mathrm{Fe}(\mathrm{CN})_{0} \\
\mathrm{NaNO}_{3} \\
\mathrm{NaNO}_{2} \\
\mathrm{Na}_{3} \mathrm{PO}_{4} \\
\mathrm{Na}_{2} \mathrm{SO}_{4} \\
\mathrm{NIS}\end{array}$ & $\begin{array}{r}26.0 \\
50.0 \\
12.2 \\
5.2 \\
3.8 \\
2.8 \\
\end{array}$ \\
\hline TOTAL & 100.0 \\
\hline Fuel/Oxidizer Ratio & .418 \\
\hline
\end{tabular}

The test sample charge was $49.7 \mathrm{gm}$ packed in the sample holder to a packing density of $1.26 \mathrm{gm} / \mathrm{cm}^{3}$. After the ferrocyanide sample was loaded and packed, $4 \mathrm{gm}$ of barium peroxide/aluminum igniter mixture were placed in the top $1 / 4$ inch of the sample holder in a thin aluminum foil pan.

The final as-tested sample parametirs are summarized in Table 3-2 below. 
WHC-EP-0662

Table 3-2

Final As-Tested Sople Paraneters

Test Sample

Water Content

Particle Size

Sample Packing Density

Containment Pressure

Sample Holder Diameter
InFarm-1 Bottom per Table 3-1

Dry

$106 \mu$

$1.26 \mathrm{gm} / \mathrm{cm}^{3}$

10 atil abs

25 m.m

Pre-Test Sample Temperature:

$\begin{array}{llll}\text { TC1 } & \text { TC2 } & \text { TC3 } & \text { TC4 } \\ 49^{\circ} \mathrm{C} & 66^{\circ} \mathrm{C} & 67^{\circ} \mathrm{C} & 52^{\circ} \mathrm{C}\end{array}$

Pre-Test Containment Volume Temperature and Pressure:

TC5

TC6

P

$21^{\circ} \mathrm{C}$

$21^{\circ} \mathrm{C}$

133.5 psig

In addition to the physical test sample parameters, Table 3-2 lists the actual pre-ignition test conditions as recorded just prior to the sample burn. 
WHC-EP-0662

\subsection{THST FROCWDORES}

Procedures identified in Ref. [3] and Appendix B were followed in the conduct of the test. Pre- and post-test containment volume gas samples were taken, Identifled and forwarded to whC for further analysis. 


\subsection{TRST RESUTLS}

\subsection{Propagation Rate Data}

The thermocouple data which indicate the linear reaction velocity are shown in Fig. 5-1. Table 5-1 indicates the various speed mo surements which can be obtained fron these data.

Table 5-1

Resction Speed Date for Test T0127-1

\begin{tabular}{|c|c|c|c|c|c|c|}
\hline TC* & $\underset{\mathrm{mm}}{\text { Location }}$ & $\begin{array}{l}\text { Tine } \\
\text { sec }\end{array}$ & & Reaction Pro & pagation Rate & \\
\hline TC1 & 9.53 & 14.5 & $\begin{array}{l}\mathrm{TC1} \rightarrow \mathrm{TC2} \\
2.52 \mathrm{~mm} / \mathrm{sec}\end{array}$ & & & \\
\hline TC2 & 30.16 & 22.7 & & $\begin{array}{l}\text { TC: } \rightarrow \text { TC3 } \\
2.91 \mathrm{~mm} / \mathrm{sec}\end{array}$ & & \\
\hline TC3 & 59.53 & 32.8 & & \multicolumn{3}{|c|}{$\begin{array}{l}\mathrm{TC} 3 \rightarrow \mathrm{TC} 4 \\
2.30 \mathrm{~mm} / \mathrm{sec}\end{array}$} \\
\hline TC4 & 81.85 & 42.5 & & & & $\begin{array}{l}\mathrm{TCl} \rightarrow \mathrm{TC} 4 \\
2.58 \mathrm{~mm} / \mathrm{sec}\end{array}$ \\
\hline
\end{tabular}

An overall average reaction velocity in the 25 mindiameter sample holder at $10 \mathrm{~atm}$. abs. Is $\approx 0.26 \mathrm{~cm} / \mathrm{sec}$. $(15.6 \mathrm{~cm} / \mathrm{min})$.

\subsection{Overall Containment Environment Response}

Fig. 5.2 provides the overall containment pressure and temperature response. The location in time for the post-test gas sample is shown in Fig. 5-2. 

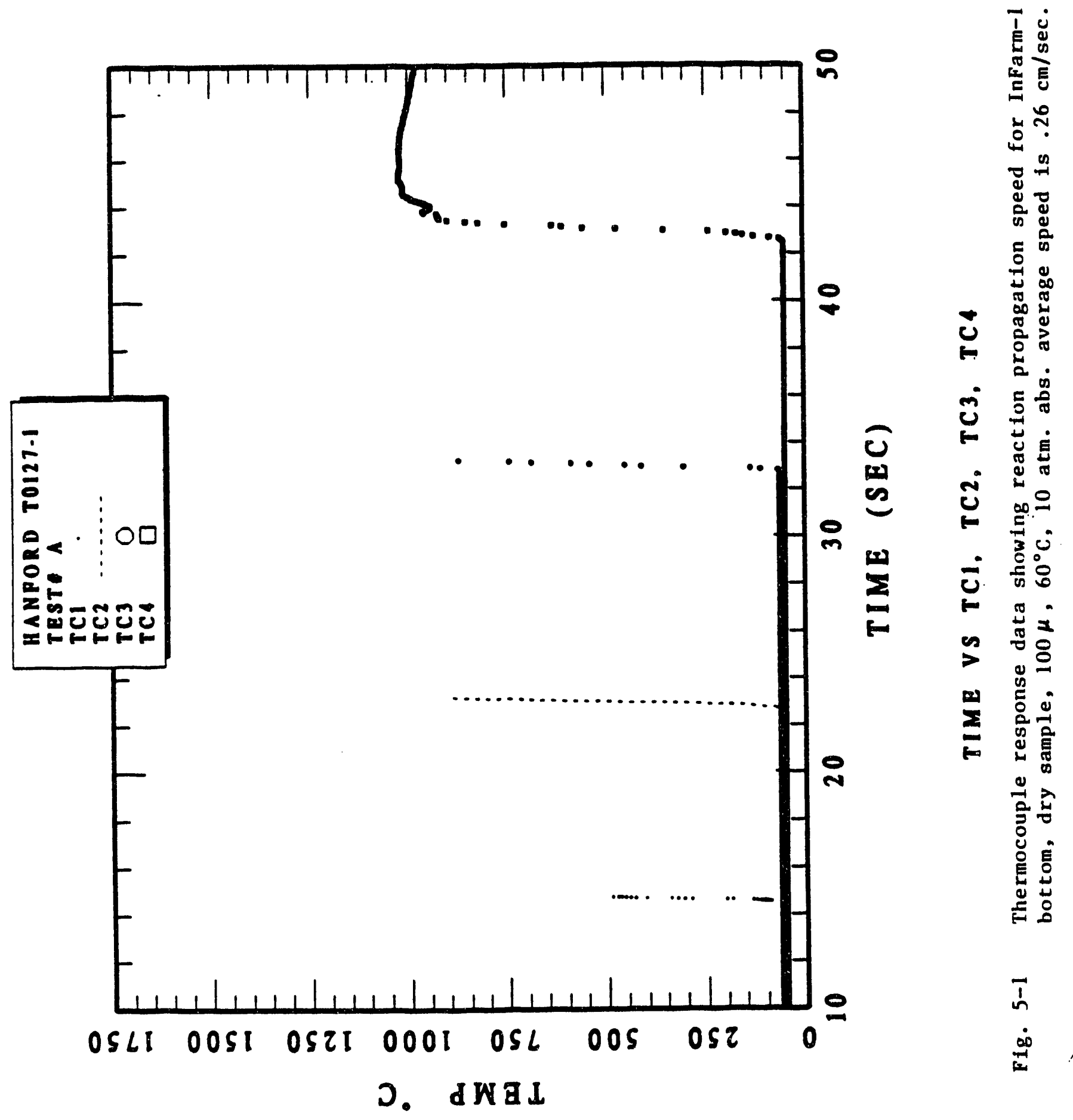
WHC-EP-0662

\subsection{Post-Test Observations}

The sample appeared to burn very hot. Significant charring of the sample holder was evident. A fine white powder residue was uniformly deposited on the floor (12" dia) of the containment vessel, but not on the top or side walls. 
WHC-EP-0662

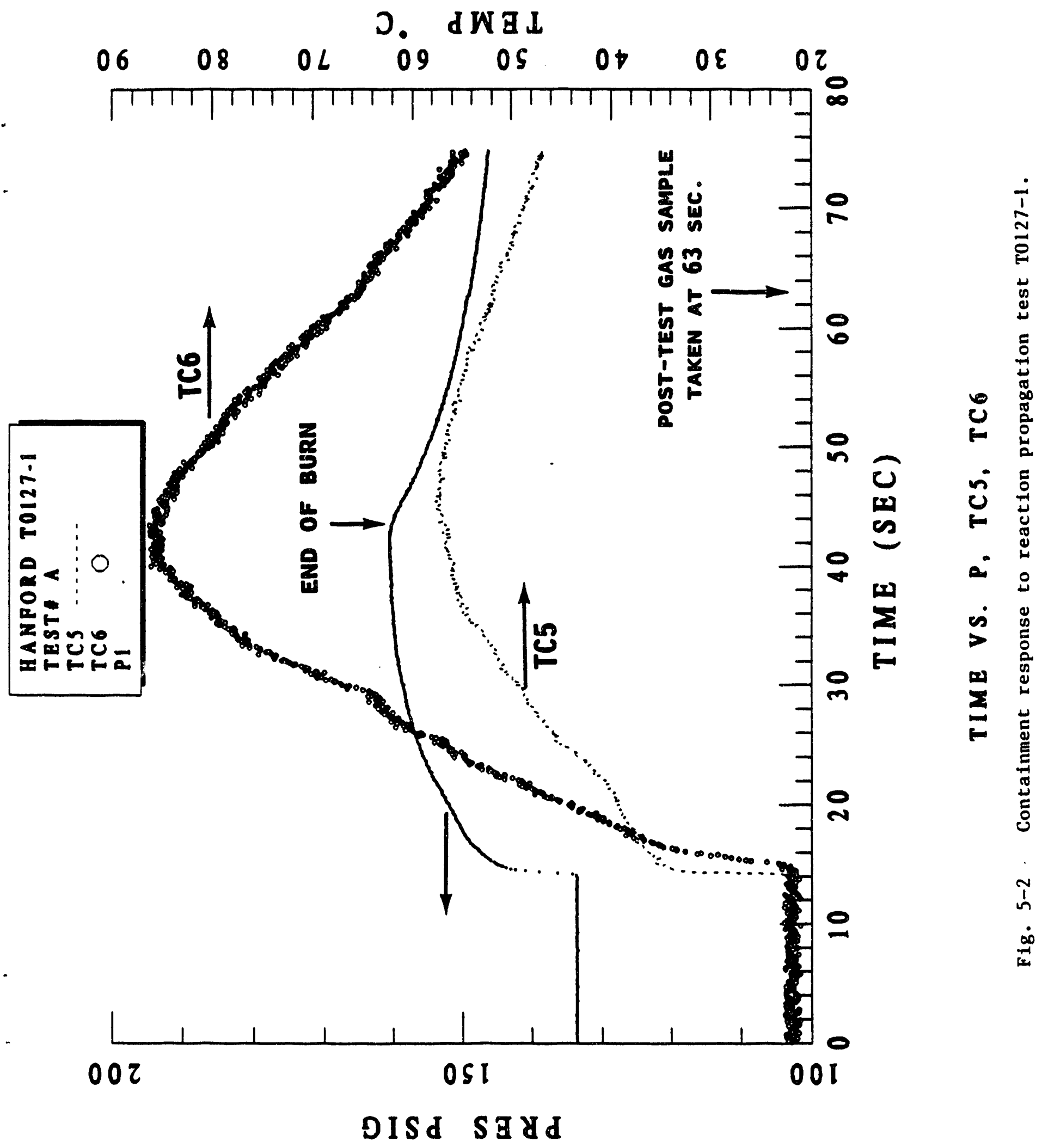




\subsection{CORPARISON TITA OTHER RETATMP RESULTS}

Table 6-1 shows a comparison of results from the present test T0127-1 with other In-Farm 1 botton reaction rate results previously reported in Ref. [4].

Table 6-1

Comparison of Related Propagation Rate Tests

\begin{tabular}{|rccccc|}
\hline Test & Material & $\begin{array}{c}\text { Pressure } \\
\text { atm }\end{array}$ & $\begin{array}{c}\text { Initial } \\
\text { Temperature } \\
\text { CC }\end{array}$ & $\begin{array}{c}\text { Specific } \\
\text { Gravity }\end{array}$ & $\begin{array}{c}\text { Reaction } \\
\text { Propation } \\
\text { Rate } \\
\text { cm/min }\end{array}$ \\
\hline T0727-1 & IF1B & 1 & 26 & 1.23 & 10 \\
*T0127-1 & IF1B & 10 & 60 & 1.26 & 16 \\
T0819-1 & VWW & 50 & 60 & 1.25 & 132 \\
\hline
\end{tabular}

* Subject of this report.

IFIB - In-Farm 1 bottom flow sheet material.

VWW - Vendor supplied material. 


\subsection{RMTPRIGES}

1. Letter; R. J. Cash to H. K. Fauske, "Subject: Aerosol Propagation Tests and Farametric Pressure Propagation Test", January 12, 1993.

2. FAI/92.66 (Revised), "Test Plans and Procedures for Determination of Reaction Propagation Velocity in Sodium Nickel Ferrocyanide Compounds", July, 1992.

3. FAI/92-81, "Adiabatic Calorimetry and Reaction Propagation Rate Tests with Synthetic Ferrocyanide Materials Including UPlant-1, UPlant-2, In-Farm 1, In-Farm 2, and Vendor-Procured Sodium Nickel Ferrocyanide", July, 1992.

4. Letter; H. K. Fauske to R. J. Cash, Subject: "Status Report on Reaction Propagation Rate Tests with Synthetic Sodium Nickel Ferrocyanide Material", September 21, 1993. 
WHC-EP-0662

APFEIDI A

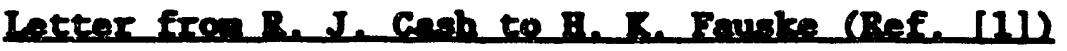

A-1 
P.O. Box 1970 Rieniand. WA 99352

January 12,1993

9350199

Dr. H. K. Fauske, President

Fauske and Associates, Inc.

16 w070 West 83rd Street

Burr Ridge, Ill inois 60521

Dear Dr. Fauske:

\section{AEROSOL PROPAGATION TESTS AND PARAMETRIC PRESSURE PROPAGATION TEST}

Please conduct two aerosol tests and one parametric propagation test for the Ferrocyanide Safety Program at Hanford. The aerosol tests are expected to give a reasonable release fraction of aerosol particles from reaction of the most concentrated ferrocyanide waste simulant, In-Farm-l. The parametric pressure propagation test will give a propagation rate measurement for an intermediate pressure.

Perform the first aerosol release test using In-Farm-l bottom fraction test material in a similar configuration as the propagation tests, except the aerosol tests shall be conducted in the 49 liter chamber. Use vacuum dried In-Farm-l simulant to which 1 wty water is added and well mixed in order to permit possible conversion of the cesium to cesium hydroxide during the reaction. Include thermocouples in the test material and within the chamber atmosphere to measure the propagation rate and containment gas/temperature responses. Perform the first test at three (3) atmospheres initial absolute pressure under argon with delayed exhaust gas venting through a filter to collect aerosol as shown in Figure 1. Other parameters should be as follows: a $25 \mathrm{~mm}$ diameter test material cylinder about $100 \mathrm{~mm}$ long, a $60^{\circ} \mathrm{C}$ initial temperature, dried material (reconstituted to 1 wty water) screened through a 140 mesh sereen, and a specific gravity of about 1.2 (actual density measured).

Venting of the chamber gas should begin when the reaction is completed as determined by the temperature of the lowest thermocouple and first decrease in chamber pressure after the reaction is started (estimated to be about 30 seconds after start of the reaction). Controlled venting down to atmospheric pressure, through an orifice upstream of the filter housing, will protect the filter system and provide favorable conditions for obtaining a good aerosol sample. The orifice should be sized to control a maximum flow through the filter of $0.5 \mathrm{cfm}$. It is important that Westinghouse Hanford Company (WHC) simulant be used instead of vendorproduced material because the WHC simulant has traceable cesium in it and the vendor material does not. 
WHC-EP-0662

H. K. Fauske

Page 2

January 12, 1993

Photographs are requested of the deposits inside of the chamber after the test. The filter papers and 0 rings from the aerosol filter should be weighed (to four significant figures) before and after aerosol loading to determine the mass of aerosol collected. (Rental of a balance, as necessary, to make these measurements is approved.) Quartz filter papers will be used and should be handled with tweezers only, since sodium can be picked up from human hands. Filter paper holders have been provided to you for handiing and shipping purposes.

It is desirable to make a material balance on the cesium and other metallic elements during this test. The inside of the chamber should be lined with aluminum foil to collect any cesium plate-out on exposed surfaces. The aerosol should be removed from the vent gas by filtering, and all of the remaining solid reaction products should be weighed. The gas samples, loaded filter paper, solid reaction products, and foil liner should be returned to WHC for analysis as soon as possible after completion of each test.

Perform the second aerosol test at an initial temperature of $120^{\circ} \mathrm{C}$ but with a)l other conditions kept the same as the first test; the same data measurements should be made. It is expected that the 1 wt $\%$ water added to the test material will be retained within the sample at $120^{\circ} \mathrm{C}$ up to the point of ignition of the second test reaction.

Please submit the aerosol propagation test procedure for WHC approval prior to conducting these tests.

It is requested that you perform one additional propagation test at an initial pressure of 10 atmospheres absolute using an argon environment. Use dry ( 0 wty water) In-Farm-l bottom fraction material for this test, the $25^{\mathrm{mm}}$ diameter test bed, an initial temperature of $60^{\circ} \mathrm{C}$, a specific gravity of about 1.2 (actual density measured), and a particle size as screened through a 140 mesh screen. This test can be conducted in the 49 liter chamber, if you choose. Obtain a gas sample of the containment atmosphere before and after the reaction. please provide a detailed gas sampling procedure for approval prior to conducting this test. Use of the WHCprovided samplers (NUPRO) with end caps to provide a second seal and to protect threaded connections is requested. Please report the results of these tests, including the temperatures of the chamber gas as a function of time, in a sumary report, available for public release.

Please provide measured gas temperatures within the containment atmosphere (and provide the location of the thermocouples) as a function of time for each propagation test conducted to date with the disodium mononickel ferrocyanide mixtures. The gas temperatures and pressure measurements during the reaction time and during cooling time are desired. Temperature and pressure measurements of the containment gas atmosphere are al so needed at the time that the gas samples were/are obtained. Your prompt response to this request for tests completed to date would be appreciated. 
H. K. Fauske

Page 3

January 12,1993

About $1.4 \mathrm{~kg}$ of additional In-Farm-l bottom fraction simulant material was shipped to you on January 5, 1993. The composition of the In-Farm-l bottom fraction simulant is still being deiermined by laboratory analysis and will be provided to you in the near future so that the final six screening propagation tests can be conducted. About one $\mathrm{Kg}$ of U-PIant-1 sludge will be prepared and shipped to you for the bake out tests discussed at the December 9 and 10, 1992 meeting at Hanford. Additional gas sampler (NUPRO) containers are also being shipped to you.

For your information the gas analysis of the containment atmosphere gases for four propagation tests conducted previously are listed in Table 1 . It should be noted that analytical results of two of the pretest samples indicate that there is a concern about the initial condition of the test chamber atmosphere. Either the gas sampling was not conducted properly or the containment atmosphere was not adequately purged. See footnotes of Table 1.

Please address questions to D. W. Jeppson at (509) 376-6058 or to me at (509) 373-3132.

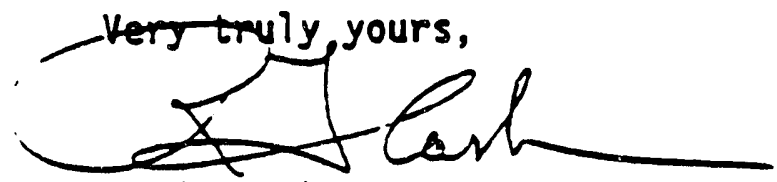

R. J. Cash, Manager

Ferrocyanide Safety Technology

Tank Waste Remediation System

fin 


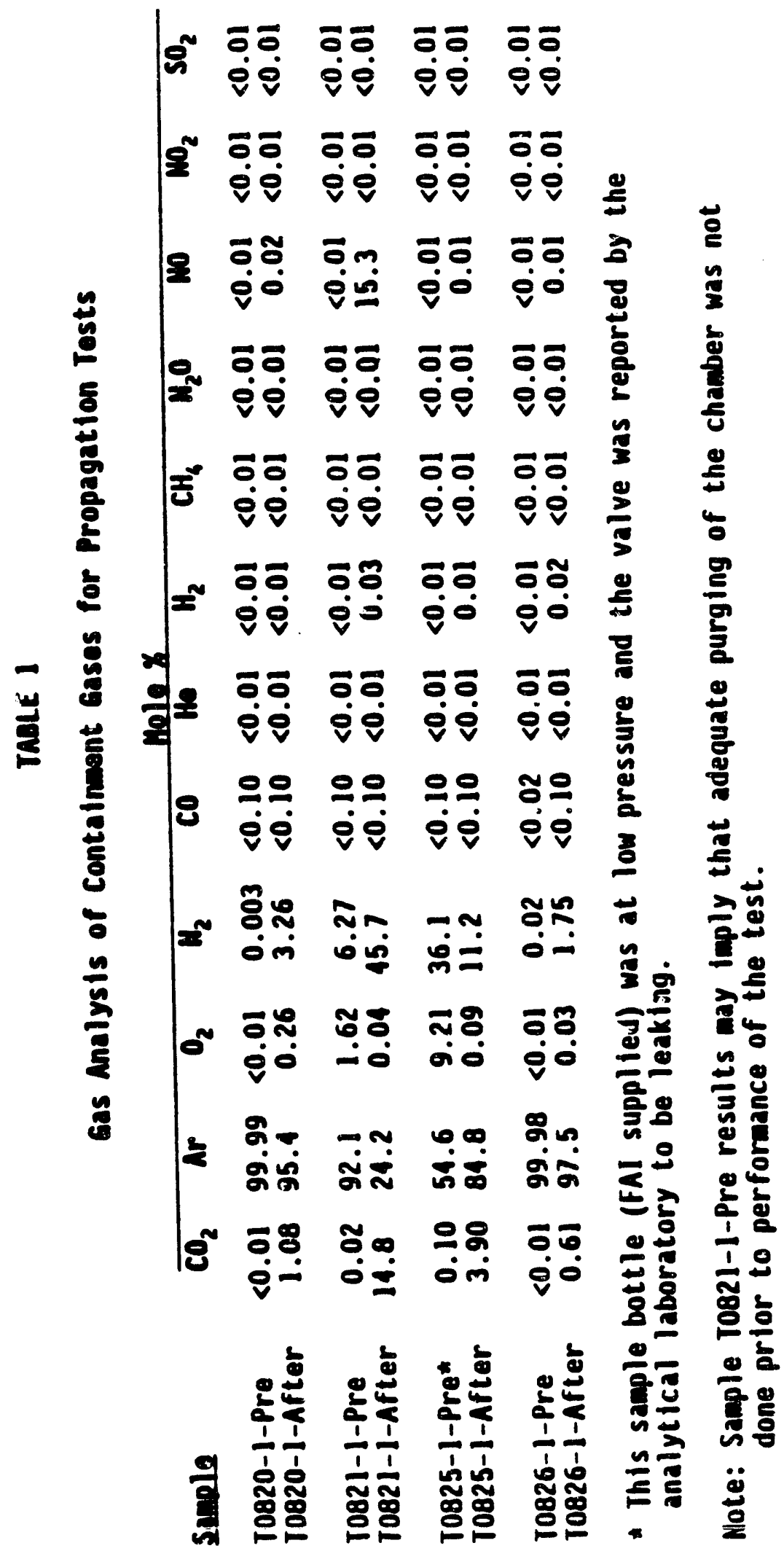


H. K. Fauske

Page 5

January 12, 1993

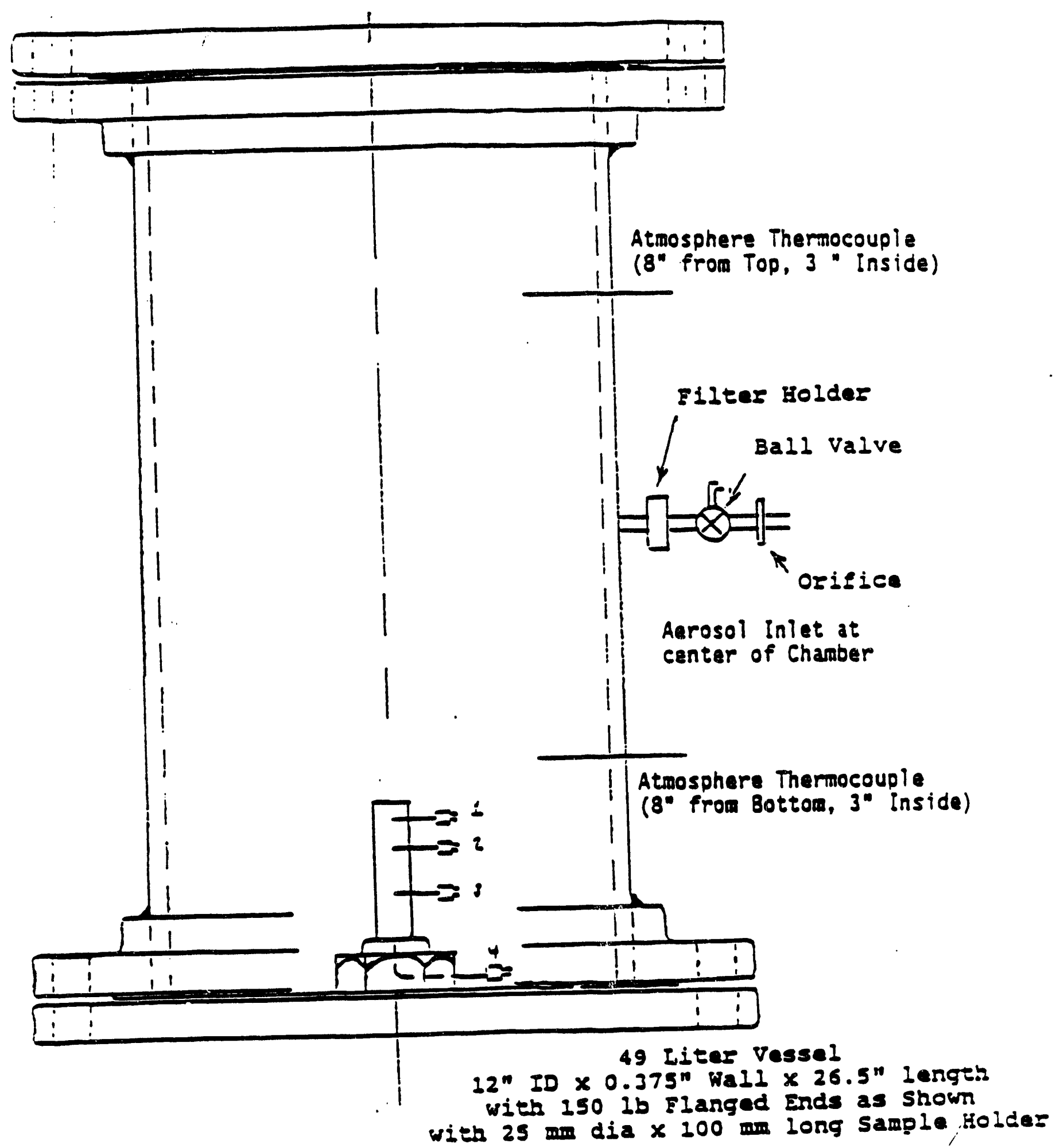

Eigura 1

Aerosol Test Containment Vessel 
WHC-EP-0662

AFHDI B

Tent Procedurees

B-1 
WHC-EP-0662

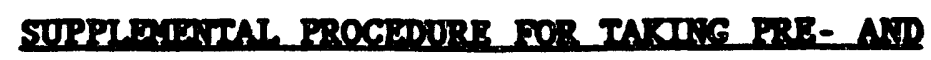

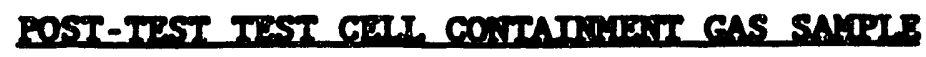

(REVISED: $26 \mathrm{Jan}$ 93)

\subsection{INTRODUCTION}

This operating procedure covers the taking of test cell containment gas samples for ferrocyanide reaction race propagation tests conducted for Westinghouse Hanford Company and supplements the general test procedures as defined in Ref. [1]*. The procedure is designed to provide consistency and uniformity in the gas sample taking operations and ainimize the potential for unwanted leakage or other sources of loss of data.

\subsection{PROCEDURE}

This procedure is subdivided into four parts. Part 1 defines the pretest sample cylinder preparations and test cell containment purge. Part 2 define the pre-test gas sample taking activity. Part 3 defines the posttest sample taking activity. Part 4 covers the gas sample identification procedures.

\subsection{PRE-TEST PREPARATIONS}

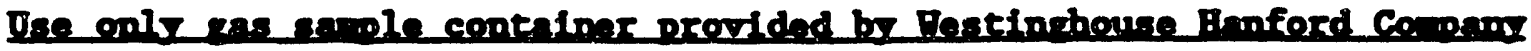

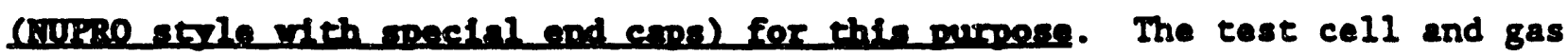
sample Installation will be conflgured as shown in FIg. 2.1-1. However, prior to achieving this conflguration both the containment volune and the gas sanple cylinder connection lines must be prepared and checked for leak tightress.

*. FAI/92.66 (Revised), "Test Plans and Procedures for Determination of Reaction Propagation Velocity in Sodiun Nickel Ferrocyanide Compounds", (July, 1992). 


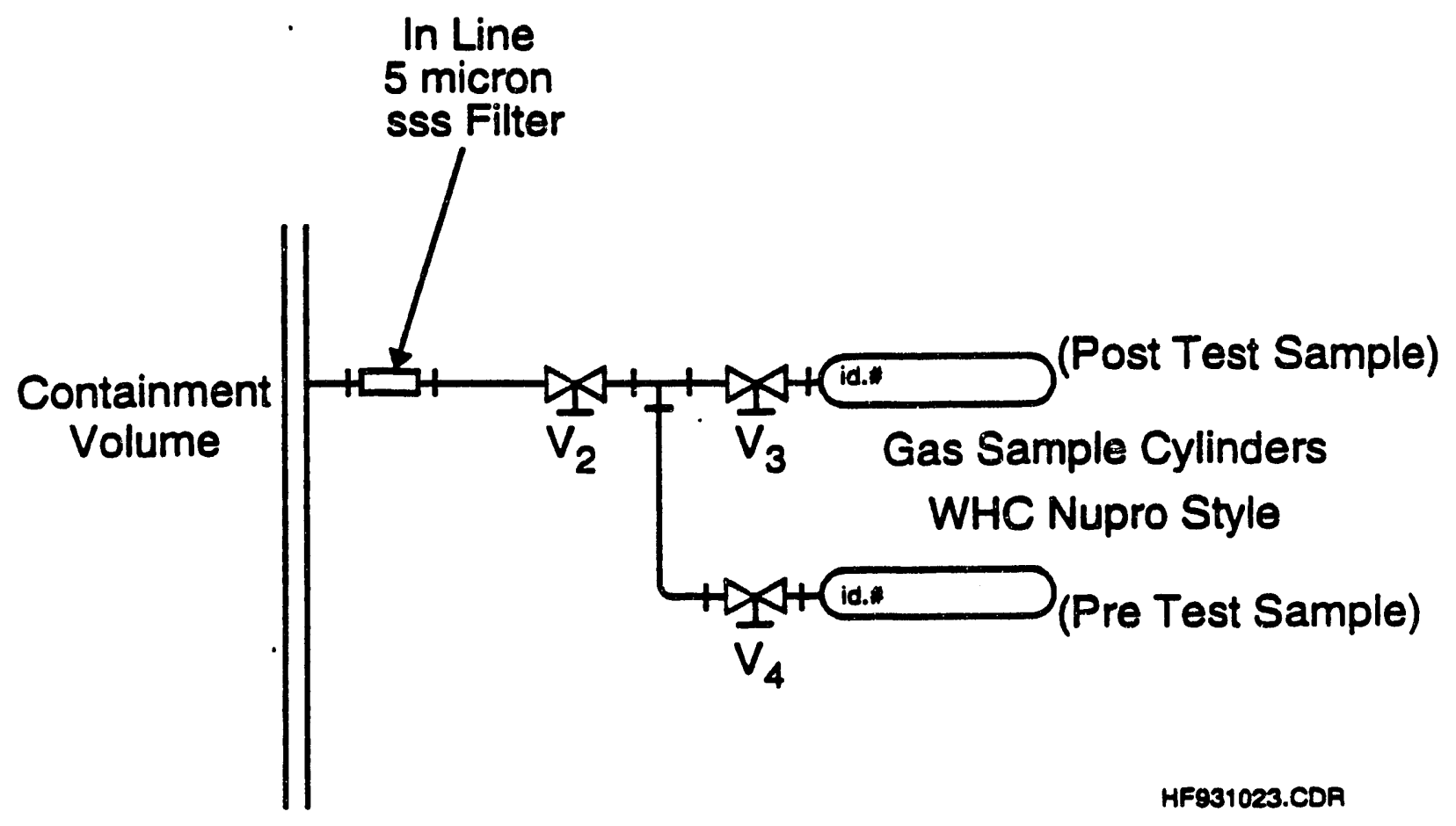

Figure 2.1-1 Installed gas sample cylinders. 


\section{1 .1 GAS SAMPIE CYIINDER}

(1) Label gas sample cylinder and valve.

see

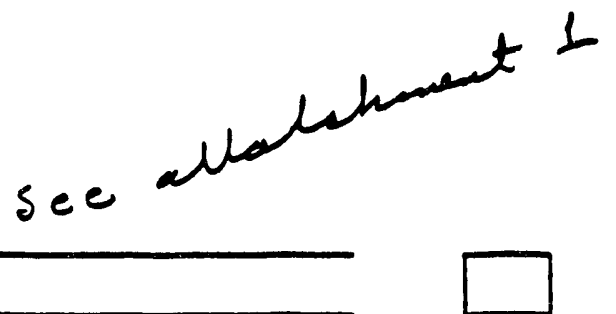

Label ID

Date of this verification

(2) Prior to test purge two cylinders for each test for five

cycles and for each cylinder end the last cycle with a 30 min evacuation:

(2.1) Label each gas sample cylinder with test ID number and designated pre- and post-test sample.

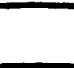

(2.2) Purge and evacuate with gas sample cylinder configured according to Fig. 2.1-2.

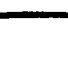

VACUUM HOLD

\begin{tabular}{|c|c|c|c|}
\hline MIN & IINE & CYCLE & VACUTY \\
\hline 10 & to & 1 & \\
\hline 10 & to & 2 & \\
\hline 10 & to & 3 & \\
\hline 10 & to & 4 & \\
\hline 30 & to & 5 & \\
\hline
\end{tabular}

(2.3) At end of purge, cap gas sample cylinder unt1l ready for use.

\section{1 .2 CONTAINATHNT VOIUTYE}

The containment volume fittings and flanges should be checked for leak tightness at some time prior to testing. This section of the procedure assures a proper argon test atmosphere and verifies the leak tight status.

Prior to the test (propagation reaction rate test) the containment volume should be 99.9 argon or better and be set at the prescribed test pressure. Since on-site analysis of the containment environment is not 


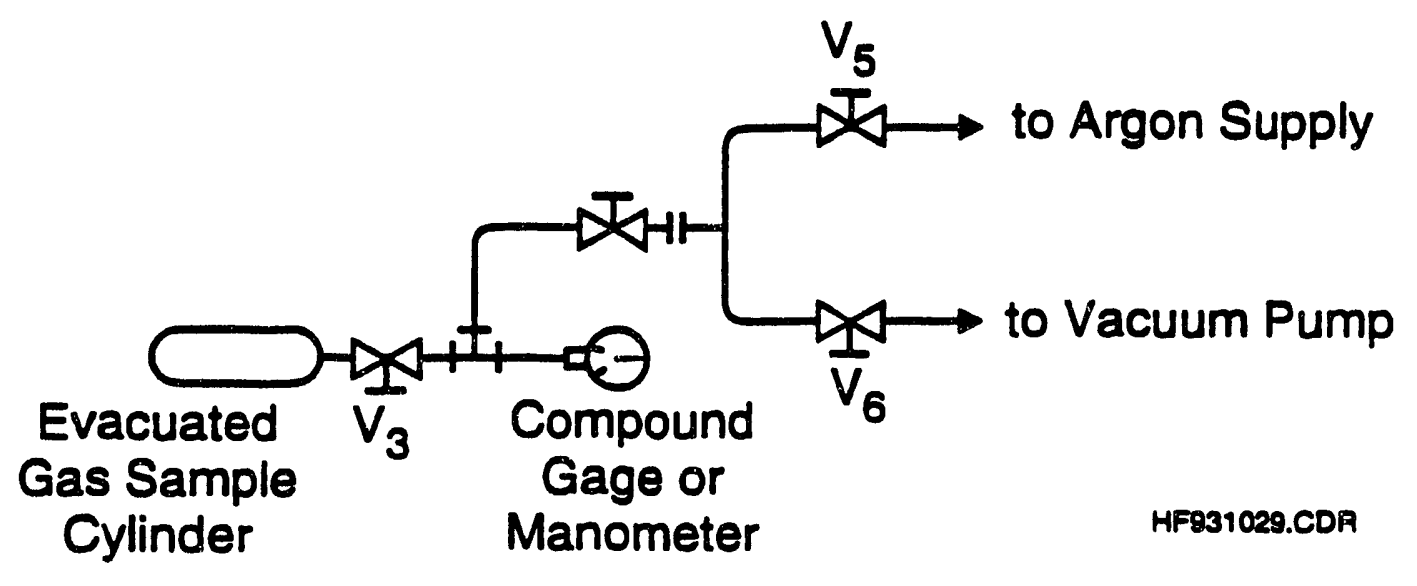

Figure 2.1-2 Configuration of gas sample cylinder for purging and final evacuation. 
possible, the desired argon atmosphere will be established by a five cycle evacuation and argon fill procedure.

Purging of the containment volume should be completed fust prior to the test activities. The purge configuration is shown in Fig. 2.1-3. The purge procedure is as follows:

(1) Attach prepared gas sample cylinders to valve $V 2$ per Fig. 2.1-3.

(2) Set up for purge per Fig. 2.1-3.

Valve Configuration -

v1 Open

V2 Open

V3 $\& 4$ Closed

V5 \& V6 Used for purge cycles.

v7 $\& 8 \quad$ Open

(3) Purge cycle - record pressure readings.

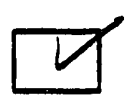

$\begin{array}{ccc}\text { CYCLE } & \text { VACUIY } & \text { EIII } \\ 1 & - \\ 3 & - \\ 5 & -\end{array}$

(4) At end of purge cycle: Close V2 and V7 remove manometer or low range pressure transducer and cap valve, $v 7$.

(5) Pressure contalnment to test pressure and check for leaks must hold pressure within 28 for $1 \mathrm{hr}$ (Note: If leaks are discovered and cannot be flxed at pressure, reduce pressure, fix leak and repeat purge procedure). 


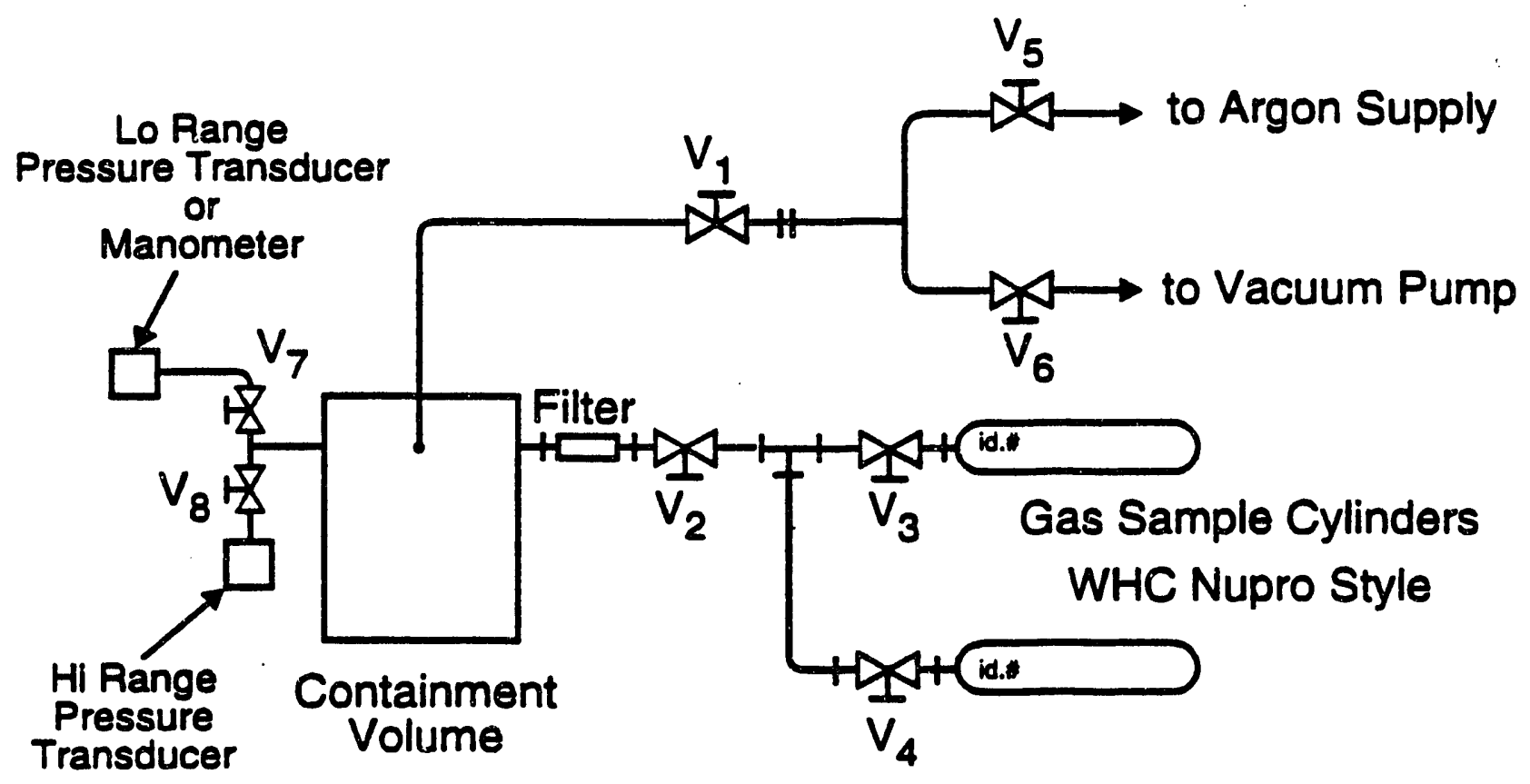

HF931021.CDR

Figure 2.1-3 Configuration of test apparatus for purging. 


\subsection{PRE-TEST GAS SAMPIE TAKING ACTIVITY}

(1) Containment vessel is leak tight and at pressure.

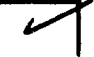
Record: Pressure $134^{\circ} \mathrm{C}$

Temperature $21^{\circ} \mathrm{C}$

(2) Open V2 and V3 - hold open for $30 \mathrm{sec}$.

(3) Record containment vessel.

Record: Pressure $\frac{133,5^{\circ} / \mathrm{g}}{21^{\circ} \mathrm{C}}$

(4) Close V2 and V3. Adjust contalnnent vessel pressure if

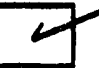
required. nen veyter.

(5) Bemove and cap geor sample ertinder

(6) Attach properly labeled post-test gas sample cylinder to test apparatus per Fig. 2.1-1.

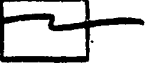

(7) Run test per established test plan.

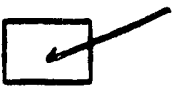

\subsection{POST-TEST GAS SAYPIE_ACTIVITY}

(1) After test burn is verified as soon as practical Record: Time After start of Test 48 sece 18 rec after bern completed

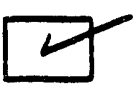

Pressure
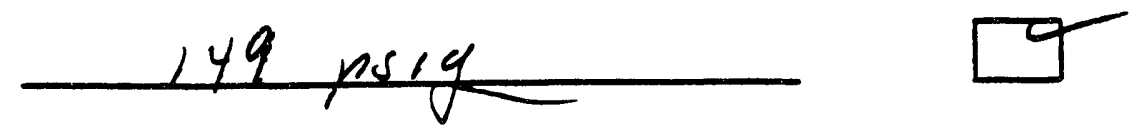

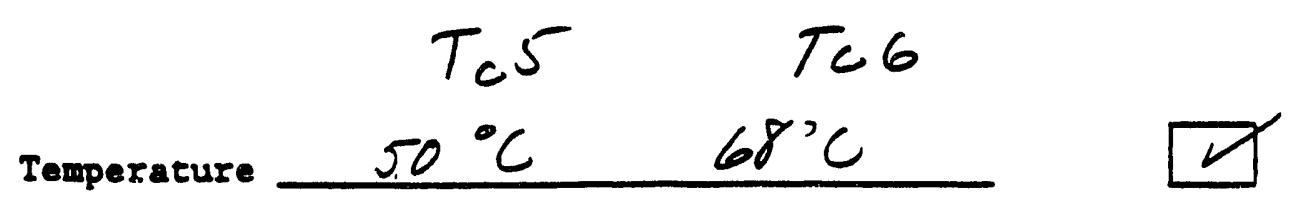

(2) Open V2 and V3 - hold open for $30 \mathrm{sec}$.

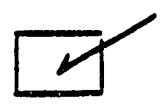

(3) Record containment vessel -
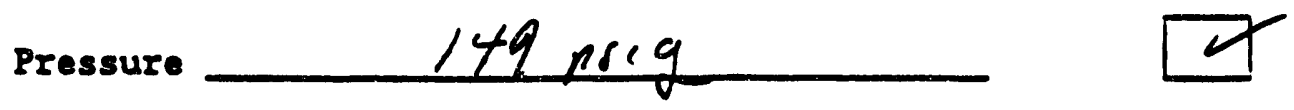

Temperature

SAME

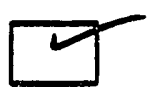

(4) Close V2 and V3.

(5) Remove and cap gas sample cylinder.

\subsection{IDENTIFICATION VRRIFICATION}

Verify pre- and post-test gas sample identification and transfer data to following sumary table.

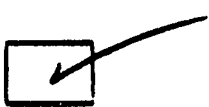


WHC-EP-0662

GAS SAMPIE SUMMARY DATA SHEET

IEST ID $T 0 / 27-1$

DATE $27 \mathrm{Jan} 93$

\section{BRB-TRST GAS SAYTIS:}

(a) Gas Sample Cylinder Identification: FH/ 1

(b) Cyllnder Volume: $50 \mathrm{cc}$

(c) Test Label as Shipped: TEST $0127-1$ peetert gas semple ll centarker at 135 aspe

(d) Pre-Sample Pressure:

(e) Containment Volume:

Pressure

Before Sample:

After Sample:
Temperature

$\frac{21^{\circ} \mathrm{C}}{21^{\circ} \mathrm{C}}$ TCSSTCG

\section{POST-IRST CAS SAYPTB:}

(a) Gas Sample Cylinder Identification: FAI 2

(b) Cylinder volune: $50 \mathrm{cC}$

(c) Test Label as Shipped: Test $T 0127-1$

A

PEST TEST GAS SAMPLE

$\frac{\text { Cylinder Pressure } 140 \text { pste }}{\text { infaren } 2 \text { BotTon } 3 \text { uen }}$

(d) Pre-Sample Pressure: Semen ad ed above

(e) Containment Volume:

Pressure

Before Sample:

After Sample:
144 asig

144
Temperature

\begin{tabular}{cc}
$40^{\circ} \mathrm{C} 41^{\circ} \mathrm{C}$ & $T_{6} S j T 66$ \\
11 & 11 \\
\hline
\end{tabular} 


\subsubsection{GAS SAMPIE CXIINDER}

(1) Label gas sample cylinder and valve.

Label ID (FHI-1) PRETFST SAMPLE A

Date of this verification $26 \sqrt{2}{ }^{\prime} 93$

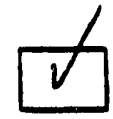

(2) Prior to test purge two cylinders for each test for five cycles and for each cylinder end the last cycle with a 30 min evacuation:

(2.1) Label each gas sample cylindar with test ID number and designated pre- and post-test sample.

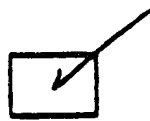

(2.2) Purge and evacuate with gas sample cylinder configured according to Fig. 2.1-2.

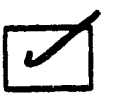

$$
\begin{aligned}
& \text { nin Vacuum Hold } \\
& 0 \text { o9:50 to } \frac{10: 00}{10: 11} \\
& 0 \text { 10:01 to } \frac{10: 25}{10: 12} \text { to } \\
& 0 \frac{10: 37}{11: 15} \\
& \text { o } 10: 26 \text { to }
\end{aligned}
$$

$\begin{array}{cc}\text { CXCLE } & \frac{28^{\prime \prime}}{2} \\ 1 & \frac{28^{\prime \prime}}{28^{\prime \prime}} \\ 3 & \frac{28^{\prime \prime}}{28^{\prime \prime}} \\ 4 & \end{array}$

EIIR $\angle A P S I G$$$
10,25
$$$$
\text { LOPSIG }
$$$$
\angle O P S / G
$$

$x$

(2.3) At end of purge, cap gas sample cylinder unt1l ready for use. Hold

\section{1 .2 CONTAINMENT VOLUME}

The containment volume fittings and flanges should be checked for leak tightness at some tine prior to testing. This section of the procedure assures a proper argon test atnosphere and verifies the leak tight status.

Prior to the test (propagation reaction rate test) the containment volume should be 99.9 argon or better and be set at the prescribed test pressure. Since on-site analysis of the containment environment is not 


\subsubsection{GAS SAMPLE CYOINDTR}

(1) Label gas sample cylinder and valve.

Label ID (FYI-2) POST TEST SMMrLE $A$

Date of this verification 26 Jan 93

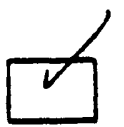

(2) Prior to test purge two cylinders for each test for five cycles and for each cylinder end the last cycle with a 30 ain evacuation:

(2.1) Label each gas sample cylinder with test ID number and designated pre- and post-test sample.

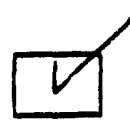

(2.2) Purge and evacuate with gas sample cylinder configured according to Fig. 2.1-2.
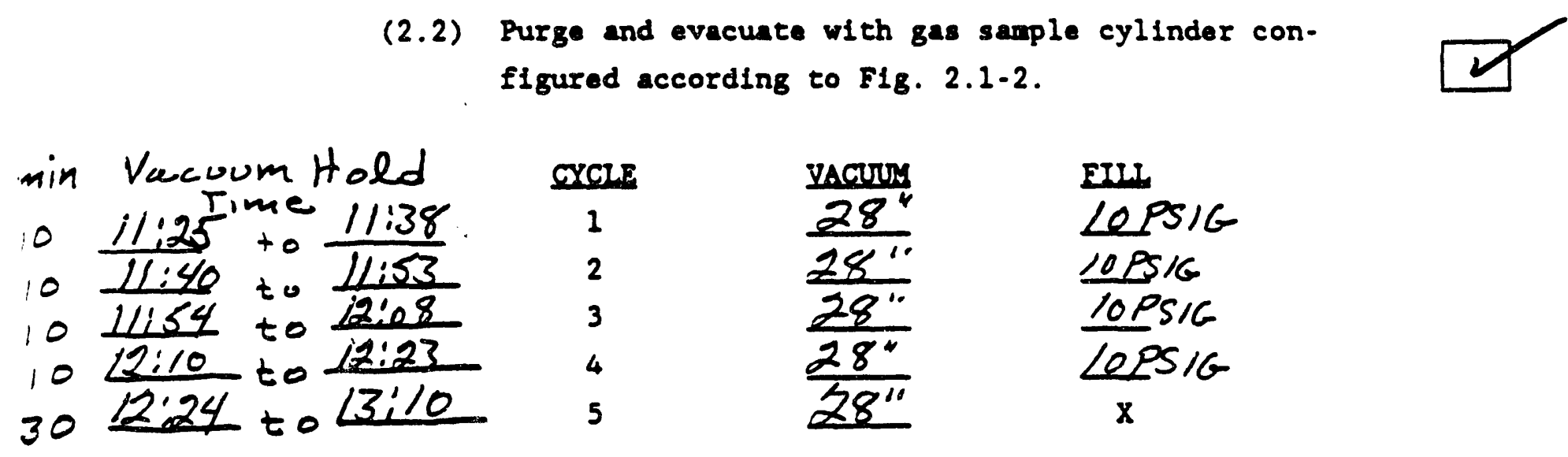

Crex:
1
2
3
4
5

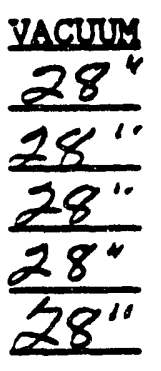

EIIL $\angle O P S I G$ 10 PSIG lOPSIC lOPSIG $\mathrm{x}$

(2.3) At end of purge, cap gas sample cylinder until ready for use. Hold

\section{1 .2 CONTAINRENT VOLUTVE}

The contalnment volume fittings and flanges should be cheiked for leak tightness at sone time prior to testing. This section of the procedure assures a proper argon test atmosphere and verifles the leak tight status.

Prior to the test (propagation reaction rate test) the containment volume should be 99.9 argon or better and be set at the prescribed test pressure. Since on-site analysis of the contalnment environment is not 


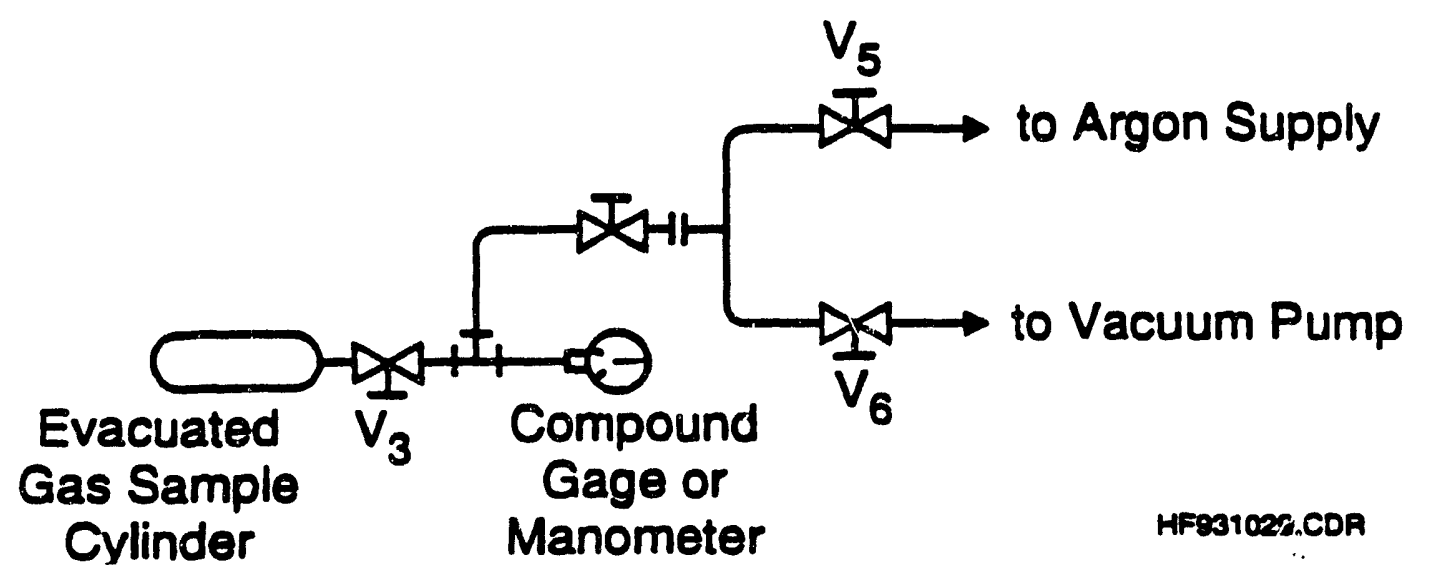

\footnotetext{
Figure 2.1-2 Configuration of gas sample cylinder for purging and final evacuation.
} 
possible, the desired argon atmosphere will be established by a five cycle evacuation and argon fill procedure.

Purging of the containment volume should be completed just prior to the test activities. The purge configuration is shown in Fig. 2.1-3. The purge procedure is as follows:

(1) Attach prepared gas sample cylinders to valve V2 per F18. 2.1-3.

(2) Set up for purge per F1g. 2.1-3.

Valve Configuration -

$\begin{array}{ll}\text { v1 } & \text { Open } \\ \text { V2 } & \text { Open w1th end capped } \\ \text { v3 \& V4 } & \text { Closed } \\ \text { v5 \& V6 } & \text { Used for purge cycles } \\ \text { v7 } \& \text { v8 } & \text { Open }\end{array}$

(3) Purge cycle - record pressure readings.

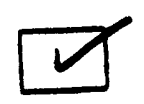

$\begin{array}{cc}\text { Crate } & \frac{\text { vacury }}{26^{\prime \prime}} \\ 1 & \frac{26^{\prime \prime}}{26^{\prime \prime}} \\ 3 & \frac{26^{\prime \prime}}{26^{\prime \prime}} \\ 4 & \end{array}$

EIII.

lOPSIG

$\angle D P S 1 G$

OPSIG

$\angle O P S I G$

13400130 psig

(4) At and of purge cycle: Close V2 and V7 remove manometer

or low range pressure transducer and cap valve, $V 7$.

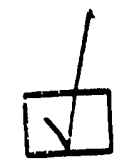

(5) Pressure containient to test pressure and check for leaks mest hold pressure within 28 for 1 hr (Nore: if leaks are discovered and cannot be flxed at pressure, reduce pressure, fix leak and repeat purge procedure). 
WHC-EP-0662

APRED G

Mreallmans Tent Daten Bacerds

C-1 


\section{Daen Shaet Foren L-001}

Raset1or Proparation Tant

Dete $-\ldots-\ldots-\ldots$

Tese ID

Marerial

F111 Hefghe

Mass

Intelal Pressuro

Intelal Taperature

Final Presare

Flnal Gas Touperacure/ILo

Tese Conflguration

Gas Samplo

Residue Srmple
$22 \operatorname{sen} 93$

$T 0127-1$

In Fenm 1 Bethene

See exthtehed Sheet $49.7 \mathrm{~m}$

130 psir nominal $60^{\circ} \mathrm{C}$ namingl See Tent Betw

Seedsta

Seedata shect

PHen if ren

Yos $X$. No $\square$

Yee $X$ No

Iose Nores Test undusted in

49utetwenel. Opentim retefectry.

crater

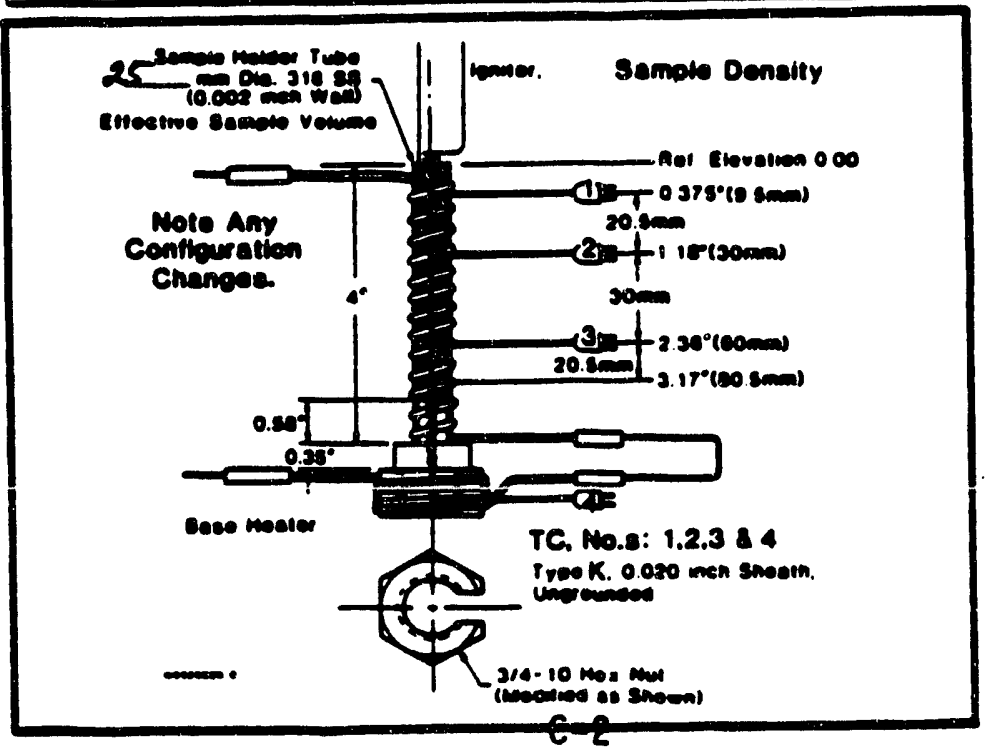




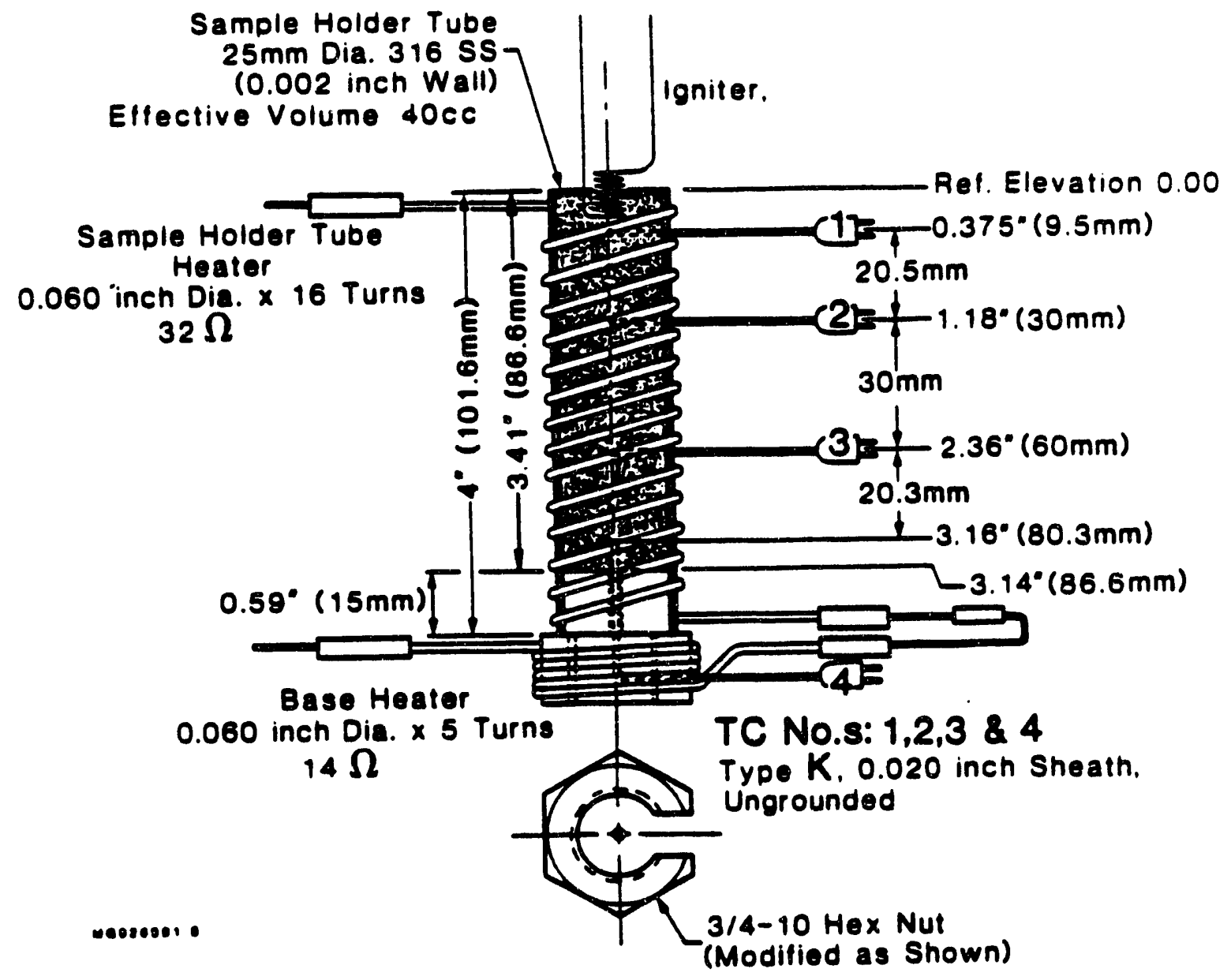

818. 2-3 25 dianeter sample holder used in burn velocity tests. 
WHC-EP-0662

$26 \operatorname{Tan} 1993$

WHC PRONAGHTHON TEST $A$

TEST PRESSURE loatmalo

SAMPLE TEMPERHTURE
$50127-1 \quad 1993$

130 psig

$60^{\circ} \mathrm{C}$

SAMPLE hOLdere $25 \mathrm{~mm} d i 2 \times 101 \mathrm{~mm} \mathrm{l}$

Verify dimensions

Overall height

$$
\frac{4.0^{\prime \prime}}{N \cdot \frac{64}{58}}
$$

Contarnment $49 \mathrm{~L}$

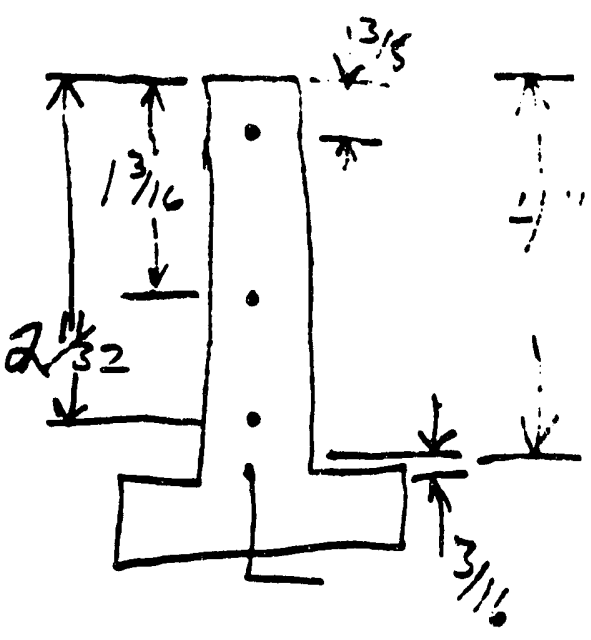

$$
\begin{array}{lll}
T C 5 & \text { Ho. } \frac{104}{105} \text { bottom } \\
\text { To } 6 & \text { No. }
\end{array}
$$

Pressures Transducen

High Range $200 \mathrm{AsI}$ Cal Fec 40.0 PSi/volt

Lo Kange CalFac psi/rolt

Sample: INFHRM-1 Bottom O\% water Ref: INEARM 2R REV 3-8-26-92

sogm) Sample $w_{y}+\frac{49.7}{\text { sample } h t} 2 m$

$$
S G \frac{1.18}{1}
$$

Ign!terw $w_{g}+\frac{4.0 \mathrm{gm}}{r}$

C-4 
WHC-EP-0662

Date $22 \mathrm{~J} 2 \mathrm{n} 23$

Calculation of Sample Test To122-1 rachel Denise.

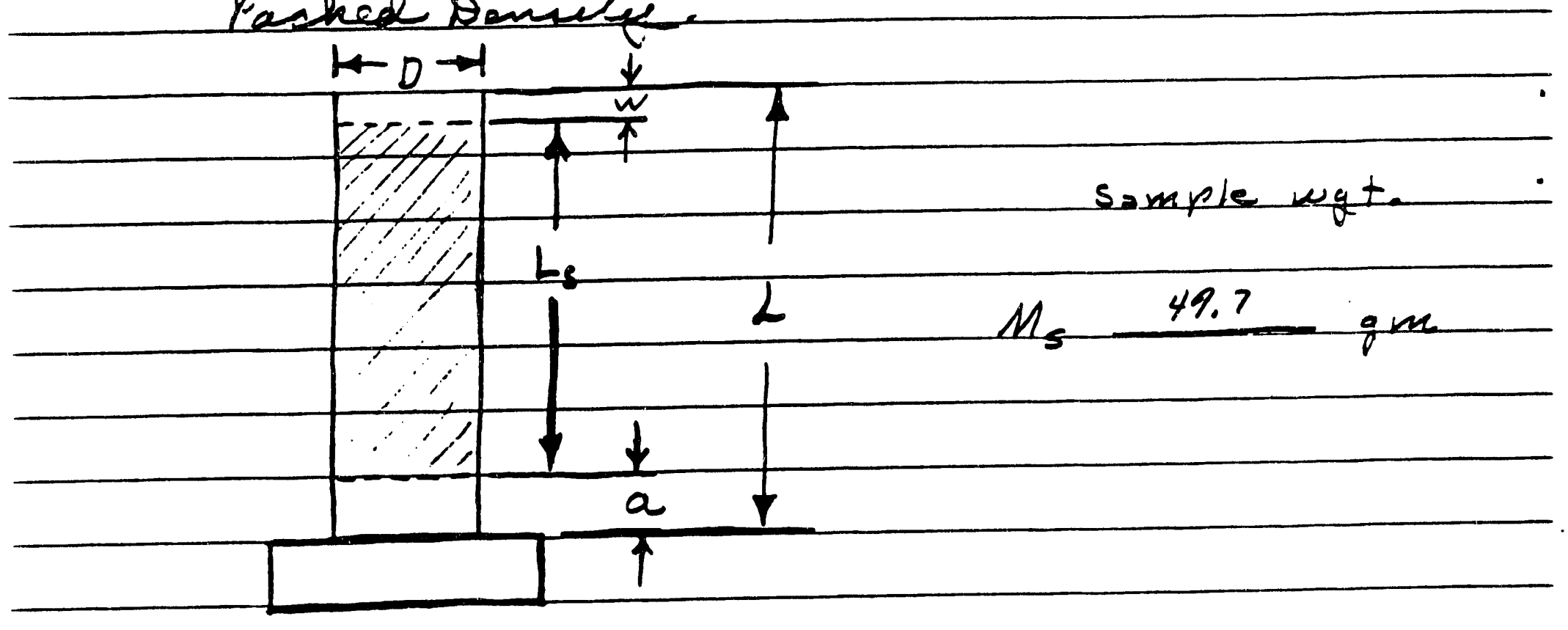

D $25 \mathrm{~mm}$

a $\quad 4.0$ inch $101.6 \mathrm{~mm}$

w $1 / 4$ inch $6.4 \mathrm{~mm}$

$L_{\delta}=\alpha-(a+w)=80.2 \mathrm{~mm}$

use dimensions in (mm)

$V_{s}=\frac{\pi D^{2}}{4} L_{s} \times 10^{-3} \quad 39.36 \mathrm{~cm}^{3}$

Packing Density $=\frac{M_{s}}{V_{s}} \frac{49.7}{39.36}=1.26 \frac{2 \mathrm{~m}}{\mathrm{~cm}^{3}}$

C-5 
WHC-EP-0662

DISTRIBUTION

Number of copies

OFFSITE

12

U.S. Department of Energy

EM-35, Trevion II

Washington, D.C. 20585

John C. Tseng

1

U.S. Department of Energy

Savannah River Operations office

P.0. Box A

Aiken, South Carolina 29808

Thomas C. Temple

1

Charles S. Abrams

1987 Virginia

Idaho Falls, ID 83404

1

David 0. Campbell

102 Windham Road

Oak Ridge, TN 37830

1

Fred N. Carlson

6965 North 5th West

Idaho Falls, ID 83401

1

Donald T. Oakley

40912 th Street SW, Suite 310

Washington, DC 20024-2188

1

Arl in K. Postma

3640 Ballard Road

Dallis, Oregon 97338

1

William R. Prindle

1556 Crestline Drive

Santa Barbara, CA 93105

1

Alfred Schneider

5005 Hidden Branches Drive

Dunwoody, GA 30338

1

Air Products \& Chemicals. Inc.

7201 Hamilton Blvd

Allentown, PA 18195-1501

George E. Schmauch 
WHC-EP-0662

\section{DISTRIBUTION (cont)}

Number of copies

OFFSITE

1

Battelle Columbus Laboratories 505 King Avenue

Columbus, $\mathrm{OH}$ 43201-2693

James A. Gieseke

2

Brookhaven National Laboratory Upton, NY 11973

Kamal K. Bandyopadhyay

Morris Reich

1

Design Science, Inc.

163 Witherow Road

Sewickley, PA 15143

Gary Powers

1

Fauske and Associates, Inc.

16 W070 W. 83rd St.

Burr Ridge, IL 60521

Hans K. Fauske

1

Florida State University

Department of Chemistry B-164

Tallahassee, FL 32306

Greg R. Choppin

1

Harvard University

295 Upland Avenue

Newton Highlands, MA 02161

Melvin W. First

1

Hazards Research Corporation

200 Valley Road, Suite 301

Mt. Arlington, NJ 07856

Chester Grelecki

1

Lawrence Livermore National Laboratory

P.0. Box 808, L-221

Livermore, CA 94550

Billy C. Hudson

Distr-2 
WHC-EP-0662

\section{DISTRIBUTION (cont)}

Number of copies

OFFSITE

4

Los Alamos National Laboratory

P.0. Box 1663

Los Alamos, NM 87545

Steve F. Agnew

Steve W. Eisenhawer

Thomas E. Larson

L. Harold Sullivan

1

MIT/Department of Nuclear Engineering

77 Massachusetts Ave.

Room 24-102

Cambridge, MA 02139

Mujid S. Kazimi

1

Nuclear Consulting Services, Inc.

P.0. Box 29151

Columbus, $\mathrm{OH} 43229$

J. Louis Kovach

Oak Ridge National Laboratory

1

Emory D. Coll ins

P.0. Box 2008

7930, MS-6385

Oak Ridge, TN 37831-6385

1 Charles W. Forsberg

P.0. Box 2008

MS-6495

Oak Ridge, TN 37831-6495

1

Thomas S. Kress

P.0. Box 2009

9108, MS-8088

Oak Ridge, TN 37831-8088

1 Rice University

5211 Paisley

Houston, TX 77096

Andrew S. Veletsos

Distr-3 
WHC-EP-0662

\section{DISTRIBUTION (cont)}

Number of copies

OFFSITE

1

Sandia National Laboratory

P.0. Box 5800

Albuquerque, NM 87185

Scott E. Slezak

4

Science Applications International Corporation 12850 Middlebrook Road

Trevion I, Suite 300

Germantown, MD 20874

Ray S. Daniels (3)

John M. Saveland

1

University of South Carolina

Department of Electrical and Computer Engineering

Swearingen Engineering Center

Columbia, SC 29208

Joseph S. Byrd

1

University of Washington

Center for Process Analytical Chemistry

Chemistry Department BG-10

Seattle, WA 98195

Bruce R. Kowalski

Vanderbilt University

P.0. Box 1596, Station B

Nashville, TN 37235

Frank L. Parker

ONSITE

U.S. Department of Energy. Richland Field office

R. F. Christensen (6)

A4-02

R. E. Gerton

A4-02

A. G. Krasopoulos

A5-55

Public Reading Room

A $1-65$

RL Docket File (2)

A3-11 
WHC-EP-0662

\section{DISTRIBUTION (cont)}

Number of copies

ONSITE

9

Pacific Northwest Laboratory

R. T. Allemann

K7-15

S. A. Bryan

P7 -25

B. M. Johnson

$\mathrm{K} 1-78$

M. A. Lilga

R. D. Scheele

G. F. Schiefelbein

D. M. Strachan

PNL Technical Files

$\mathrm{P} 8-38$

P7 -25

P8-38

Hanford Technical Library

$\mathrm{K} 2-38$

P8-55

63

Westinghouse Hanford Company

H. Babad

R2-08

D. B. Bechtold

T6-50

J. R. Bell

D. C. Board

R3-09

G. L. Borsheim

S1-57

V. C. Boyles

R2-11

S. L. Bradley

R1-49

R. J. Cash (5)

B3-06

M. D. Crippen

R2-32

G. M. Christensen

L5-31

R. D. Crowe

S. J. Dechter

C. DeFigh-Price

J. L. Deichman

H4-21

H4-62

D. R. Dickinson

R2-50

R2-31

B1-59

G. T. Dukelow (2)

L5-3]

G. L. Fox

R2-32

G. T. Frater

L5-01

J. C. Fulton

R1-51

K. A. Gasper

R2-31

J. M. Grigsby

R2-08

H4-62

H. D. Harmon

R2-52

J. M. Held

R3-12

M. N. Islam

R3-08

J. R. Jewett

T6-50

N. W. Kirch

R2-11

C. A. Kuhlman

B3-30

M. Kummerer

H4-62

J. D. McCormack

L5-31

J. M. McLaren

HO-34

J. E. Meacham

R2-32

N. J. Milliken

H4 -62

A. F. Noonan

R2-12

J. W. Nieskas

R2-1i

P. C. Ohl

H5-09 
WHC-EP-0662

\section{DISTRIBUTION (cont)}

Number of copies

ONSITE

Westinghouse Hanford Company (cont)
P. M. Phelps
B3-30
D. N. Price
R2-14
J. G. Propson
R2-18
R. E. Raymond
R1-80
F. R. Reich
L5-63
D. A. Reynolds
R2-11
B. C. Simpson
R2-12
S. R. Tifft
H6-16
H. Toffer
R. K. Welty
W. P. Whiting
J. C. Wiborg
W. D. Winkelman
HO-38
R1-80
B3-25
H4-60
D. D. Wodrich
L5-55
W. F. Zuroff
B1-59
Central Files
Document Processing and Distribution (2)
R2-14 EDMC
L8-04
Information Release Administration (3)
L8-15
H6-08
TFIC
$\mathrm{R} 1-08$
R1-20 

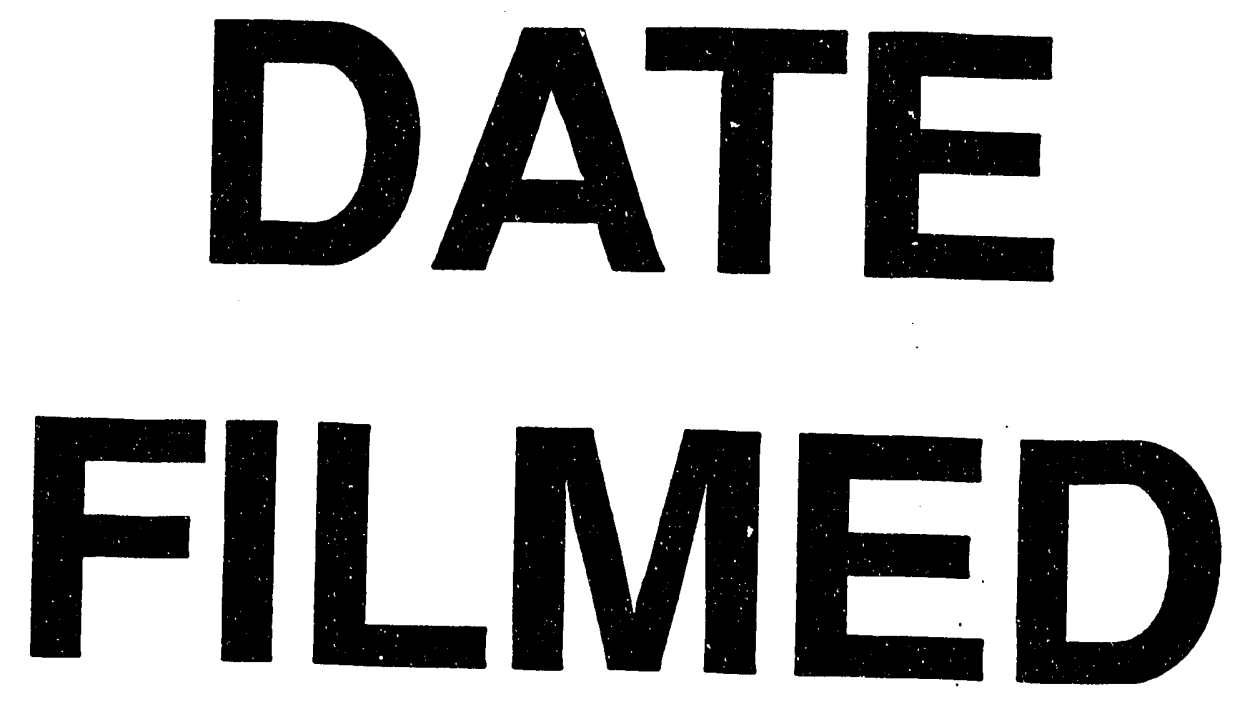

$10 / 13 / 93$
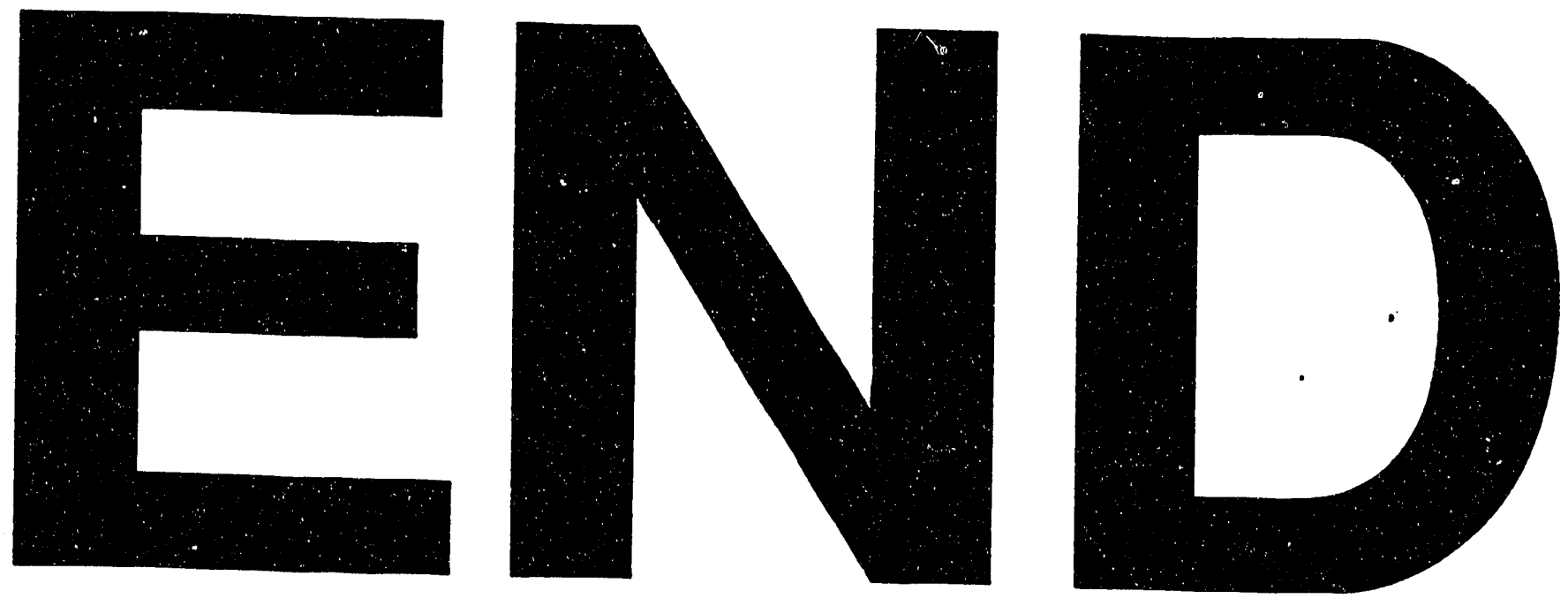